\title{
Pros and cons of L-arginine supplementation in disease
}

\author{
Yvonne L. J. Vissers ${ }^{1}$, Iris B. J. G. Debats ${ }^{2}$, Yvette C. Luiking ${ }^{1}$, Rajiv Jalan ${ }^{3}$, René R. W. J. van der Hulst ${ }^{2}$, \\ Cornelis H. C. Dejong ${ }^{1}$ and Nicolaas E. P. Deutz ${ }^{1 *}$ \\ ${ }^{1}$ Department of Surgery, Maastricht University, PO Box 616, NL-6200 MD Maastricht, The Netherlands \\ ${ }^{2}$ Department of Plastic Surgery, Maastricht University, Maastricht, The Netherlands \\ ${ }^{3}$ Department of Hepatology, Royal Free and University College Medical School, London, UK
}

\begin{abstract}
The amino acid arginine and one of its metabolites NO have gathered broad attention in the last decade. Although arginine is regarded as a conditionally essential amino acid in disease, L-arginine supplementation in severe illness has not found its way into clinical practice. This might be due to the invalid interpretation of results from studies with immune-enhancing diets containing L-arginine amongst other pharmaconutrients. However, not much attention is given to research using L-arginine as a monotherapy and the possibility of the alternative hypothesis: that L-arginine supplementation is beneficial in disease. The present review will discuss data from studies in healthy and diseased animals and patients with monotherapy of L-arginine to come to an objective overview of positive and negative aspects of L-arginine supplementation in disease with special emphasis on sepsis, cancer, liver failure and wound healing.
\end{abstract}

L-Arginine supplementation: Nitric oxide: Sepsis: Cancer: Wound healing: Liver failure

\section{Introduction}

The amino acid arginine and one of its metabolites, NO, have gathered broad attention in the last decade. This is related to the fact that arginine is not merely a component of proteins, but also participates in various metabolic processes, and is the direct precursor of NO. As such, arginine has been suggested to have important functions in pathophysiology, such as sepsis, trauma and wound repair (for reviews, see Barbul, 1990; Kirk \& Barbul, 1990; Kelly et al. 1995; Tzeng \& Billiar, 1997; Witte \& Barbul, 2002). Although arginine is regarded as a conditionally essential amino acid in disease, L-arginine supplementation in severe illness has not found its way into clinical practice.

This is probably due to the fact that conclusions regarding L-arginine supplementation derive mainly from studies using commercially available nutritional supplements containing, besides L-arginine, other nutrients such as nucleotides and $n-3$ fatty acids (for example, Impact ${ }^{\circledR}$; Novartis, Minneapolis, MN, USA or Immune-Aid ${ }^{\circledR}$; McGaw, Irvine, CA, USA). From such studies, it has recently been concluded that L-arginine-containing enteral nutrition products should not be used in critically ill patients (Heyland et al. 2001; Heyland \& Samis, 2003). In general, two major problems exist with this kind of studies. The first problem is that a mixture of nutrients is used; from a scientific point of view, this complicates interpretation of the results, since it is impossible to determine which nutrient is responsible for the effects. Besides, these ingredients could interact antagonistically. The second problem is that control groups are often not present or are not supplied with isonitrogenous and/or isoenergetic amounts; this makes it difficult to conclude whether treatments should be attributed to the specific pharmaconutrients or simply to the addition of amino acids and/or energy in general.

Therefore, the present review will only discuss studies using L-arginine as a monotherapy. It will focus on L-arginine supplementation in sepsis, cancer, liver failure and wound healing. It will not discuss effects on atherosclerosis. The pathophysiology of arginine and NO in atherosclerosis (Arnal et al. 1999; Napoli \& Ignarro, 2001; Gewaltig \& Kojda, 2002; Napoli, 2002; Rekka \& Chrysselis, 2002; Harrison \& Cai, 2003; John \& Schmieder; 2003; Mungrue et al. 2003; Prior et al. 2003) and the effects of L-arginine supplementation in animal models and human patients with atherosclerosis (Tentolouris et al. 2000; Boger \& BodeBoger, 2001; Preli et al. 2002; Tousoulis et al. 2002) have been reviewed several times in the last years.

\footnotetext{
Abbreviations: ADMA, asymmetric dimethylarginine; NOS, $\mathrm{NO}$ synthase; $\mathrm{NO}_{\mathrm{x}}$, nitrate and nitrite. *Corresponding author: Dr Nicolaas E. P. Deutz, fax +31 43 3882126, email nep.deutz@ah.unimaas.nl
} 


\section{Arginine metabolism}

In most mammals, arginine is traditionally considered a conditionally essential amino acid (Rose, 1976; Cynober et al. 1995; Wakabayashi et al. 1995; Young \& Yu, 1996), because during growth and metabolic stress the endogenous production of arginine can become insufficient (Windmueller \& Spaeth, 1981; Newsholme \& Leech, 1983). The normal daily intake of arginine is about 5-6 g (Visek, 1986; Heys \& Gardner, 1999), whilst whole-body arginine flux ranges between 15 and $20 \mathrm{~g} / \mathrm{d}$ (Castillo et al. 1995, 1996; Cynober et al. 1995).

\section{Metabolic pathways of arginine}

Apart from being an essential component of proteins, arginine plays a key role in several other metabolic pathways (Wu \& Morris, 1998; Heys \& Gardner, 1999) (Fig. 1). It is a precursor in the synthesis of polyamines; putrescine, spermine and spermidine (Barbul, 1990; Cynober, 1994). These compounds are important in the growth and differentiation, for example, of intestinal mucosal cells (Cynober, 1994). Arginine is also a precursor for urea synthesis in the liver (Cynober et al. 1995) as well as in the kidney (Bankir, 1996; Morel et al. 1996), and as such plays an important role as a waste $\mathrm{N}$ carrier in the urea cycle. Besides this, arginine is a precursor in the hepatic and renal synthesis of creatine (Perez et al. 1978; Visek, 1986; Heys \& Gardner, 1999), an important constituent of skeletal muscle (Wu \& Morris, 1998). Arginine, also, appears to be converted by the enzyme arginine decarboxylase (EC 4.1.1.19) to agmatine, a metabolite that has been suggested to play a role in cell signalling and proliferation (Wu \& Morris, 1998).

Finally, via arginase, arginine is an indirect precursor for collagen formation through ornithine and proline, and as such is involved in the production of extracellular matrix molecules by fibroblasts (Schaffer et al. 1999), both important in wound healing. In this context, arginine has also been suggested to have immunotrophic effects. It stimulates

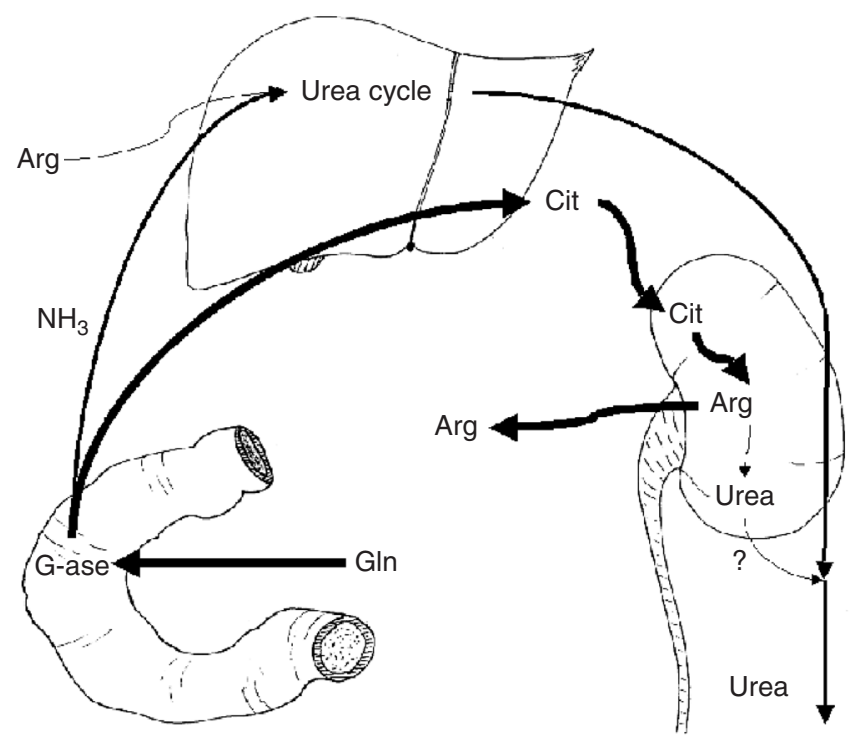

Fig. 1. Inter-organ arginine metabolism. the release of growth hormone and its peripheral mediator insulin-like growth factor-1, it stimulates the release of prolactin (Cynober, 1994; Heys \& Gardner, 1999) and glucagon (Visek, 1986) and has the strongest insulinogenic effect of all amino acids (Barbul, 1990). Furthermore, both arginine and NO are important mediators in T-cell mediated immunity (Daly et al. 1988), cytokine induction (Reynolds et al. 1990) and macrophage-mediated bacterial toxicity (Hibbs et al. 1987). Recently, it has become clear that NO synthase (NOS)2 and arginase act together in vivo to control specific types of T-cell responses (Bronte et al. 2003).

\section{Nitric oxide}

Arginine is the sole precursor of NO synthesis through the NOS (EC 1.14.13.39) pathway (Castillo et al. 1995; Roth, 1998). Three isoforms of NOS exist; NOS1, NOS2 and NOS3, formally named neuronal, inducible and endothelial NOS. All isoforms appear to be present in non-stimulated conditions, including NOS2 (Miller et al. 1995; Hoffman et al. 1997). Microbacterial products and inflammatory cytokines can up regulate NOS2 (Morris \& Billiar, 1994). It has been reported that NOS3 is down regulated at the same time (Chen et al. 1997). This suggests interaction between NOS isoforms, each regulating the expression of the other.

NO currently receives considerable attention in view of its widespread effects, especially in the cardiovascular system (Guarner et al. 1993), where it functions as a signal molecule in vasodilatation and angiogenesis (Lee et al. 1999). Through these same mechanisms, NO is involved in wound healing as it indirectly provides the wound area with sufficient $\mathrm{O}_{2}$ and nutrition. This stimulates fibroblasts to synthesise collagen and keratinocytes to proliferate and thus NO takes part in building up repair tissue in the wound.

NO is a scavenger of superoxide radicals to form peroxynitrite (Szabo, 1996; Titheradge, 1999), which can be considered to be a beneficial mechanism. However, in conditions of reduced arginine availability NOS enzymes produce both superoxide and peroxynitrite (Xia et al. 1996), which probably should be regarded as a negative effect. Large amounts of NO, its by-products, or both can exert toxic effects, including mitochondrial dysfunction leading to further impairment in $\mathrm{O}_{2}$ delivery and extraction (Preiser $e t$ al. 2003). As an example, the overproduction of NO has been suggested to result in enterocyte apoptosis or necrosis at the villus tips (suggested to be due to peroxynitrite formation in intestinal villi). Overproduction has also been suggested to result in the inhibition of mitochondrial respiration in enterocytes, and intestinal mucosal barrier dysfunction as evidenced by increases in bacterial translocation (Oudenhoven et al. 1994a; Unno et al. 1997; Mishima et al. 1998; Dickinson et al. 1999). Therefore, whilst limited NO production may be beneficial to the organism, excess NO production should probably be regarded as an adverse effect. This points to a 'therapeutic window' when arginine and NO metabolism is being modulated.

\section{Endogenous nitric oxide inhibition}

In the NOS enzyme system, there are several constitutive inhibitors including caveolin-1 (Ju et al. 1997; Shah et al. 
1999) and the arginine homologue asymmetric dimethylarginine (ADMA; Vallance et al. 1992; Lin et al. 2002; Kielstein et al. 2003). Inhibition of NO synthesis by the latter is counterbalanced by its catabolism by the enzyme dimethylarginine dimethylaminohydrolase, which is particularly abundant in the liver and kidney (Ogawa et al. 1987; MacAllister et al. 1996). Dimethylarginine dimethylaminohydrolase can be modulated by oxidative stress and inflammatory cytokines such as TNF- $\alpha$ (Ito et al. 1999). Other regulatory proteins are NOSTRIN (Zimmermann et al. 2002) and NOSIP (Dedio et al. 2001; Konig et al. 2002), which may alter the trafficking of the NOS3 protein to calveolae for interaction with the substrate arginine, or inhibit NOS3 activity by competing with arginine for binding.

\section{Effects of arginine availability on nitric oxide production}

Arginine availability for NO synthesis is regulated by de novo arginine synthesis, cellular arginine transport and arginase activity (Hallemeesch et al. 2002b). Increases in arginine uptake and in endogenous arginine synthesis collaborate to maximise cellular capacity for NO synthesis (Morris \& Billiar, 1994). Reduced arginine availability could therefore reduce NO synthesis. Following an intraperitoneal injection of endotoxin in mice with elevated NO production rates, enhanced de novo arginine synthesis from citrulline in the kidney was suggested as an adaptive mechanism to sustain systemic NO production (Hallemeesch et al. 2002a,c). Moreover, following an intraperitoneal injection of endotoxin in NOS-knockout mice, the increase in circulating arginine correlated well with the rate of NOS2-mediated NO production, but not with NOS1- and NOS3-mediated NO production (Hallemeesch et al. 2003). The importance of (extracellular) arginine availability for NO synthesis is also illustrated by the finding that arginine depletion by arginase reduces NO production in rats with endotoxic shock (Bune et al. 1995). When L-arginine was supplied either enterally or parenterally in a porcine model of sepsis, L-arginine appeared a determining factor in the endogenous synthesis of NO (Bruins et al. 2002c). However, the expected correlation between plasma levels of citrulline and arginine and NO production (assessed as plasma levels of nitrate) was not found in septic and trauma patients (Ochoa et al. 1991).

\section{Measuring nitric oxide production}

NO indices vary in the literature; both conversion products of NO in the body (nitrate and nitrite), direct gas analysis and isotopic techniques have been used to detect changes in NO metabolism (for a review of techniques, see Luiking \& Deutz, 2003). Plasma nitrate is often used as a measure of NO production (Guarner et al. 1993; Oudenhoven et al. $1994 b$ ). However, discrepancies between the degree of plasma nitrate or nitrite increases and actual NO production have been described in animal models (Bruins et al. 2002a,c; Hallemeesch et al. 2002c), although recently a good correlation between NO production rate and plasma nitrite was shown in mice after an intraperitoneal injection of endotoxin (Hallemeesch et al. 2003). As plasma nitrate levels depend on the rate of synthesis and elimination by urinary excretion, diminished renal function in sepsis may be a confounding factor, making the interpretation of these studies difficult (Kirkeboen \& Strand, 1999).

\section{Inter-organ arginine metabolism}

The synthesis of arginine is probably regulated in a more complex way than has been assumed until recently. Various organs such as the kidney, intestine and liver act together in an inter-organ axis.

\section{Kidney}

In the kidney, arginine is released into the renal vein after being synthesised from citrulline that is taken up from the renal artery (Perez et al. 1978; Brosnan, 1987; Dhanakoti et al. 1990) (Fig. 1). Quantitatively speaking, the human kidneys take up about $1.5 \mathrm{~g}$ citrulline/d from the blood (Tizianello et al. 1985). Arginine release back into the bloodstream has been reported to be between $2 \mathrm{~g} / \mathrm{d}$ (Tizianello et al. 1980, 1985) and $4 \mathrm{~g} / \mathrm{d}$ (Cynober et al. 1995 ) in man. Although it is generally believed that the kidney is the major site for de novo arginine synthesis in adult animals (Brosnan, 1987), the amount of arginine synthesised accounts for only 10-20\% of total plasma arginine flux, the remainder being derived from protein catabolism (Dejong et al. 1998; Wu \& Morris, 1998). However, the 2-4 g of arginine synthesised by the kidney equals $35-75 \%$ of normal daily arginine intake $(5 \cdot 4 \mathrm{~g})$ (Visek, 1986; Heys \& Gardner, 1999). Thus, in the physiological state, the body can provide most of the arginine required for normal functions. Whether this is also true during disease is not yet clear.

\section{Intestine}

Renal uptake of citrulline appears to be regulated by circulating citrulline levels (Dhanakoti et al. 1990). Citrulline is a non-essential (Rose et al. 1948), non-protein amino acid and a nitrogenous product of glutamine metabolism in the proximal part of the small intestine (Windmueller \& Spaeth, 1975, 1976, 1978; Hoogenraad et al. 1985; van der Hulst et al. 1997). Since the liver does not take up citrulline in significant quantities (Bankir, 1996), most citrulline synthesised by the bowel reaches the systemic circulation (Windmueller \& Spaeth, 1981) and is subsequently taken up by the kidney (Windmueller \& Spaeth, 1981; Deutz et al. 1992; Dejong et al. 1993a,b). The importance of this pathway is illustrated by the fact that arginine becomes a dietary essential amino acid when intestinal citrulline synthesis is inhibited (Hoogenraad et al. 1985), for example after intestinal resection (Wakabayashi et al. 1995) and in animals with low rates of intestinal citrulline synthesis, such as cats (Dhanakoti et al. 1990).

The metabolic link between glutamine, glutamate and arginine via citrulline is interesting, especially in the context of the assumed beneficial effects of glutamine supplementation (Heys \& Ashkanani, 1999). In man, decreased plasma citrulline levels are related to decreased glutamine concentrations as observed in nutritional depletion (van der 
Hulst et al. 1994). Studies in rats subjected to massive small-bowel resection have shown that glutamine uptake by the residual bowel was decreased (Klimberg et al. 1990b; Deutz et al. 1992) concomitant with decreased intestinal citrulline release (Deutz et al. 1992) and decreased arterial citrulline concentrations (Deutz et al. 1992; Wakabayashi et al. 1995); decreased arterial citrulline concentrations have also been found in human small-bowel resection patients (Crenn et al. 1998). Actually, the arterial concentration of citrulline has been suggested to be an indicator of the likelihood of becoming independent of total parenteral nutrition for patients with short-bowel syndrome (Crenn et al. 1998). Although this correlation between small-intestinal length and net citrulline release is well established (Deutz et al. 1992; Crenn et al. 1998, 2000, 2003), the consequences of loss of intestinal length for arginine metabolism are less well known and may differ between animals and man. We demonstrated a decreased renal citrulline uptake and renal arginine release in rats with a short bowel (Dejong et al. 1998). However, this did not affect arterial arginine concentrations (Wakabayashi et al. 1995) or whole-body arginine flux (Dejong et al. 1998). Crenn et al. (1998), however, did find decreased arterial arginine concentrations after smallbowel resection in human patients.

An interesting aspect of the inter-organ metabolic relationship between glutamine, glutamate, citrulline and arginine has been demonstrated by Houdijk et al. (1994) after enterally administered glutamine in rats. They observed a $30 \%$ increase in arterial citrulline and arginine, as well as a $40 \%$ increase in renal citrulline uptake and arginine release (Houdijk et al. 1994). This might suggest that part of the postulated beneficial effects of glutamine supplementation (Jacobs et al. 1988; Hammarqvist et al. 1989; O'Dwyer et al. 1989; Klimberg et al. 1990a; van der Hulst et al. 1993, Scheppach et al. 1994; Roth, 1998; Wernerman, 1998) are mediated by the intestinal conversion of glutamine to citrulline followed by renal conversion to arginine (Houdijk et al. 1998a). In subsequent experiments they confirmed these results (Houdijk et al. 1998b) but did not find an increase in plasma nitrate (Houdijk et al. 1998b), suggesting that NO might not be involved and also illustrating the complexity of the mechanisms involved (Houdijk et al. 1998a; Roth, 1998).

\section{Liver}

The liver is a major arginine producer, but a low expression of CAT-2A arginine transporters accounts for a low hepatic transport rate of arginine back into the circulation (White, 1985). In addition, the liver contains high levels of the cytosolic enzyme arginase-I, which breaks down arginine into urea and ornithine. Thus, although flux through the urea cycle (and hence arginine synthesis and breakdown) (350 $\mu \mathrm{mol} / \mathrm{kg}$ per $\mathrm{h}$ ) is several-fold greater than total plasma arginine flux (approximately $75 \mu \mathrm{mol} / \mathrm{kg}$ per h), this will not be detected by an assessment of whole-body kinetics (Young \& Yu, 1996; Dejong et al. 1998; Wu \& Morris, 1998). As a consequence, the liver does not release significant amounts of arginine and in the basal state only 5-15\% of urea is derived from plasma arginine (Castillo et al. 1996; Wu \& Morris, 1998).

\section{Dietary intake}

Regulation of arginine synthesis is even more complex when the effects of dietary intake are taken into account (Cynober, 1994). Normally about $60 \%$ of arginine administered through the enteral route is absorbed intact and delivered to the portal blood (Windmueller \& Spaeth, 1976; Wu \& Morris, 1998). The remainder is metabolised to ornithine $(38 \%)$, citrulline, proline, $\mathrm{CO}_{2}$ or urea and released into the portal vein (Cynober et al. 1995). Since arginine is taken up by the liver and metabolised to urea, the effect would be that on a high-protein diet enterally administered arginine tends to be scavenged by the liver (Cynober, 1994; Deutz et al. 1998). Cynober et al. (1995) have suggested that the prolonged administration of highprotein diets (rich in arginine) leads to an adaptation of the intestinal enzymic machinery leading to less arginine being converted to citrulline in the intestine during the process of absorption. As a result, more arginine administered through the enteral route would be taken up as such and would gain access to the portal vein. On the other hand, the prolonged administration of low-protein diets (low in arginine content) leads to up regulation of the intestinal enzymes ornithine transcarbamoylase and $\mathrm{N}$-acetylglutamate synthetase, resulting in more dietary arginine being converted to citrulline (Cynober et al. 1995). Since citrulline, as pointed out previously, is not quantitatively taken up by the liver, it will subsequently be converted to arginine by the kidney (arginine-sparing effect). Thus, the intestinal conversion of arginine to citrulline is an adaptive mechanism to keep hepatic urea synthesis low in conditions of reduced protein intake (Cynober, 1994).

Despite these inter-organ adaptive responses, it is possible to raise plasma arginine levels following the oral intake of L-arginine (Preli et al. 2002). Thus, at least theoretically, the oral route can be used to supplement L-arginine in attempts to influence pathophysiology.

\section{Arginine metabolism in disease}

\section{Sepsis}

Sepsis is a major health problem, as it is a common, frequently fatal, and expensive condition that generally requires intensive-care treatment. The incidence of severe sepsis in the USA is high (three cases/1000 population per annum), with an overall mortality rate of $29 \%$ increasing with age (Angus et al. 2001). Considerable effort has been undertaken to understand the pathogenesis of the disease and to improve therapy.

Although systemic vasodilatation occurs during sepsis, the regulation of microcirculatory flow seems to be lost (Poeze et al. 1999; Hiltebrand et al. 2000). A selective deficiency of arginine for NOS1- and NOS3-dependent synthesis may be present, based on the observations that NOS1 and NOS3 activity as well as the transporter protein CAT1 are down regulated (Reade et al. 2002; Scott et al. 2002; Schwartz et al. 2003). Such a deficiency could have crucial effects since NOS1 and NOS3 may have important protective effects during sepsis (Helmer et al. 2002). Exogenous arginine could therefore be needed to maintain homeostasis. 
Arginine metabolism. Plasma and intracellular muscle arginine levels are markedly reduced in sepsis (Freund et al. 1979; Milewski et al. 1982; Garcia-Martinez et al. 1993), which suggests compromised endogenous synthesis and/or increased utilisation of arginine. Muscle-protein breakdown was increased in a pig model of sepsis with lowered arginine levels (Bruins et al. 2002a), while in septic paediatric patients increased arginine oxidation was observed (Argaman et al. 2003). The potential need for arginine supplementation is further strengthened by the observation that a marked reduction in serum arginine is a predictor of mortality in patients with sepsis (Freund et al. 1979).

Nitric oxide production. Excessive NO production following the induction of NOS2 by cytokines (mainly TNF$\alpha$, and IL-1, IL-6, and IL-8) (Groeneveld et al. 1997, 1999; Annane et al. 2000; Nakae et al. 2000) plays a major role in the development of the characteristic symptoms of septic or endotoxaemic shock (Morris \& Billiar, 1994; Kelly et al. 1995; Symeonides \& Balk, 1999). The latter is generally characterised by an elevated cardiac output, systemic hypotension and pulmonary hypertension. Concomitant changes in blood flow, including microvascular flow (De Backer et al. 2002) may contribute to inadequate tissue $\mathrm{O}_{2}$ extraction and a rise in blood lactate during sepsis (Parrillo, 1993). Interestingly, although NOS2 activity is up regulated, NO production by NOS1 and/or NOS3 is down regulated in sepsis (Kirkeboen \& Strand, 1999; Beach et al. 2001; Hallemeesch et al. 2003).

Different stages of sepsis may be characterised by different degrees of NO levels (Vincent et al. 2000), as was observed from variable plasma nitrate and nitrite $\left(\mathrm{NO}_{\mathrm{x}}\right)$ levels measured for a prolonged period during and after sepsis in patients (Strand et al. 2000). Increased plasma $\mathrm{NO}_{\mathrm{x}}$ levels in sepsis have often been reported (Ochoa et al. 1991; Evans et al. 1993; Gomez-Jimenez et al. 1995; Endo et al. 1996; Groeneveld et al. 1996; de Werra et al. 1997; Adamik et al. 2000; Strand et al. 2000; MacKenzie et al. 2001), even in the absence of renal failure (Ochoa et al. 1991). Using stable isotopes, an increased whole-body production of nitrate was observed in endotoxin-induced shock in pigs (Santak et al. 1997), and an increased NO production by splanchnic organs and liver was observed in pigs during $24 \mathrm{~h}$ hyperdynamic endotoxaemia, using stable isotopes (Bruins et al. 2002a). This increased NO production was quantitatively matched by an increased arginine utilisation (Bruins et al. 2002a). One study reports an increased NO synthesis rate in critically ill septic paediatric patients (Argaman et al. 2003).

It has also been reported that patients surviving from septic shock had higher plasma $\mathrm{NO}_{\mathrm{x}}$ levels than non-survivors (Manders et al. 1999), which others attributed to diminished renal function (Adamik et al. 2000). However, the opposite has also been reported, with falling $\mathrm{NO}_{\mathrm{x}}$ levels in survivors and increased levels in non-survivors (Groeneveld et al. 1999; MacKenzie et al. 2001; Brealey et al. 2002), which illustrates the caveats in our knowledge concerning the role of $\mathrm{NO}$ in sepsis.

In this context, it is of interest to mention that although NOS inhibition in human patients provided promising results with respect to the restoration of haemodynamics in sepsis, a recent multicentre trial was terminated because of detrimental effects in the treatment group (Kilbourn, 1999; Kirkeboen \& Strand, 1999).

Why arginine or nitric oxide may be depleted. Sepsis is characterised by diminished plasma arginine levels and an increased arginine demand for NO production by NOS2. Although systemic vasodilatation occurs during sepsis, the regulation of microcirculatory flow seems to be lost (Poeze et al. 1999; Hiltebrand et al. 2000). A selective deficiency of arginine for constitutive NO synthesis may be present, based on the observations that NOS1 and NOS3 activity as well as the transporter protein CAT-1 is down regulated (Reade et al. 2002; Schwartz et al. 2003), while NOS1 and NOS3 may have important protective effects (Helmer et al. 2002). Moreover, patients are often not fed, protein breakdown is increased and de novo arginine synthesis is not elevated (YC Luiking, M Poeze, CH Dejong, G Ramsay and NE Deutz, unpublished results). Exogenous arginine could therefore be needed to maintain homeostasis.

\section{Cancer}

The presence of cancer leads to disturbances in metabolism that result in weight loss and malnutrition. The incidence of cancer cachexia, a clinical syndrome consisting of anorexia, muscle wasting and an increased use of fat tissue, varies from 3 to $80 \%$ on first patient contact (Nixon et al. 1980). When cancer patients undergo surgery, cachexia negatively affects treatment outcome and contributes to early death if left untreated.

Arginine metabolism. Plasma arginine concentrations in various types of cancer have been investigated. These have been reported to be decreased in lung cancer (Naini et al. 1988), higher in breast cancer (Park et al. 1991; Kubota et al. 1992), unchanged (Kubota et al. 1992) or higher (Glass et al. 1986) in gastrointestinal cancer, unchanged in head and neck cancer (Kubota et al. 1992) and unchanged in oesophagal cancer (Naini et al. 1988). Interpretation of the results may be complicated by difficulties in defining ideal control groups, since anorexia, cachexia and weight loss often accompany the presence of a tumour.

Arginase. Various malignant tissues such as lung (Suer Gokmen et al. 1999), skin (Gokmen et al. 2001), prostate (Keskinege et al. 2001), colon (Park et al. 1991) and breast (Park et al. 1991; Porembska et al. 2003) contain high amounts of arginase. Because of this high content of arginase, tumours might have the potential to metabolise arginine and thereby to consume arginine at the expense of other organs. Besides this, plasma arginase has been demonstrated to be higher in patients with gastrointestinal cancer with and without weight loss (Glass et al. 1986) and breast cancer (Porembska et al. 2003). These high plasma arginase levels can lower arginine availability even more.

Nitric oxide production. In the late 1980s, Hibbs showed that $\mathrm{NO}_{2}$ formation from arginine was needed for the defence against tumours (Hibbs et al. 1987). Later, NO was 
proven to be the effector molecule (Lancaster \& Hibbs, 1990) by which macrophages killed tumour cells (Stuehr \& Nathan, 1989). However, regarding NO and cancer cells, there are still conflicting hypotheses. Location, timing and concentration appear to be determining factors in the effect NO exerts on tumour cells. Some studies show that NO damages DNA (Tamir et al. 1996; Zhuang et al. 2000) while others show that NO protects against cytotoxicity (Wink et al. 1996; Yoshie \& Ohshima, 1997). Conversely, NO donors inhibited proliferation at high concentrations of $50 \mu \mathrm{M}$, but stimulated proliferation at concentrations ranging from 1 to $10 \mu \mathrm{M}$ (Ulibarri et al. 1999). On a further note, NO has been correlated both with increased (Liu et al. 2003) and decreased (Wenzel et al. 2003) apoptosis of tumours (Wink et al. 1998).

Compared with benign tissues, high levels of all three NOS isoforms have been observed in various human tumours. Increased NOS2 levels or expression have been found in tumours of the head and neck (Gallo et al. 2003; Jayasurya et al. 2003), lung (Lee et al. 2003), and brain (Kato et al. 2003). Increased levels or expression have also been found in tumours of the colon (Cianchi et al. 2003), prostate (Baltaci et al. 2001; Wang et al. 2003), bladder (Wolf et al. 2000), thyroid (Choe et al. 2003), breast (Thomsen et al. 1995; Tschugguel et al. 1999; Vakkala et al. 2000) and B-cells (Mendes et al. 2001). High NOS1 and NOS3 levels or enzymic expression were demonstrated in thyroid (Patel et al. 2002) and brain tumours (Cobbs et al. 1995). More specifically, expression of NOS2 in tumours has been correlated to apoptotic index (Vakkala et al. 2000; Kong et al. 2002; Jayasurya et al. 2003). In addition, in apoptosis, NO derived from tumour tissue has been hypothesised to play a role in tumour vascularisation. However, in vivo studies investigating these correlations for tumour and host metabolism, both in animals and patients, are lacking.

Why arginine or nitric oxide may be depleted. The presence of cancer can lead to a high use of arginine, since arginine is involved in cytokine induction in relation to an increased acute-phase response in cancer (Reynolds et al. 1988a) and tumour cytotoxicity (Hibbs et al. 1987), probably via NO (Lancaster \& Hibbs, 1990). Since tumours contain high levels of arginase (Park et al. 1991; Suer Gokmen et al. 1999), they have the potential to consume high amounts of arginine. The tumour will probably maintain its arginine consumption at the expense of other organs, leading to a high arginine waste in cancer. Indeed, changes in plasma arginine levels (Naini et al. 1988; Kubota et al. 1992) indicate that arginine-NO metabolism is altered in cancer.

\section{Liver failure}

Patients with cirrhosis present with a hyperdynamic circulation manifest as high cardiac output, low systemic vascular resistance and elevated portal pressure (Groszmann, 1993), and these haemodynamic parameters deteriorate with increasing disease severity (Braillon et al. 1986). The paradox of increased intrahepatic resistance despite low peripheral and mesenteric vascular tone and the role of vasoconstrictors and vasodilators in liver disease have still not been explained. Liver failure may be complicated by hepatic encephalopathy, characterised by elevated ammonia levels due to the failure of hepatic urea cycling. However, the precise pathophysiological mechanisms responsible for hepatic encephalopathy remain poorly defined.

Following liver transplantation, ischaemia-reperfusion injury results in parenchymal and endothelial injury due to free radical production (Goode et al. 1994), the depletion of NO (Langle et al. 1995), and the release of cytokines and chemokines (Colletti et al. 1995; Clavien et al. 1996; Gerlach et al. 1997; Lentsch et al. 1998; Boros et al. 2001). Moreover, the systemic inflammatory response causes local injury to the liver and a transient, profound cardiovascular collapse due to a combination of reduced systemic vascular resistance and myocardial depression (Aggarwal et al. 1987, 1993).

Arginine metabolism. In general the circulating levels of arginine in patients with liver disease have been suggested to be maintained (Tietge et al. 2002). But in acute hepatic encephalopathy, arginine, pathophysiologically important as an intermediate in the urea cycle, is believed to be depleted (Lavoie et al. 1987), thus further compounding increases in brain ammonia.

We and others have observed that the haemodynamic consequences of ischaemia-reperfusion injury after liver transplantation may be related to the relative deficiency of arginine in the reperfusion period (Chamuleau et al. 1987; Bzeizi et al. 1997; Yagnik et al. 2002). Immediately after hepatic reperfusion, high amounts of arginase-I are released from the graft, thereby influencing NO metabolism (Ikemoto et al. 1998). In pigs undergoing liver transplantation, plasma arginase concentrations were shown to increase 50-fold following hepatic revascularisation, which resulted in a drop in plasma levels of arginine $(-87 \%)$ and in a drop in nitrite $(-82 \%)$ and nitrate $(-53 \%)$ concentrations. The mean pulmonary arterial pressure increased 2fold, whereas the flow-pressure index of the portal vein decreased by about $60 \%$ (Langle et al. 1997).

Nitric oxide production. Whole-body NO synthesis was increased in patients with cirrhosis and this is believed to be important in modulating the hyperdynamic circulation in these patients (Vallance \& Moncada, 1991). Hepatic NO synthesis was, paradoxically, reported to be reduced in the diseased liver (Sarela et al. 1999). Furthermore, it has been demonstrated that vascular responses to vasopressor agents were also impaired in these patients, and that this may be mediated through NO (Helmy et al. 2003).

In a rat model of portacaval anastomosis, increased NOS1 protein and mRNA, as well as enzyme activity (Rao et al. 1995, 1997), have been demonstrated, with the implications of increased oxidative stress and altered cerebral perfusion through NO generation. Moreover, NO caused an increase in glutamate release from the synaptic cleft (Katchman \& Hershkowitz, 1997), which may be important following the observation of increased extracellular levels of brain glutamate in experimental liver failure (de Knegt et al. 1994). Furthermore, astrocytes, important cells in brain swelling, cultured in the presence of ammonia, showed increased arginine uptake and NOS expression (Hazell \& Norenberg, 1998). 
Endogenous nitric oxide inhibition. Impaired liver function has been found to give rise to an increased concentration of ADMA (Nijveldt et al. 2003a). Since endogenous competitive inhibitors of NO such as ADMA are compartmentalised in the liver, the paradox of high intrahepatic resistance and peripheral vasodilation in cirrhosis may result from the disparate impact of inflammation on these NOS regulatory proteins on one hand and the ongoing systemic inflammatory drive that maintains the hyperdynamic state on the other. Arginine supplementation in patients with liver failure represents a potentially beneficial method of reducing intrahepatic resistance by overriding the effects of the inhibitors of NOS, such as ADMA.

Why arginine or nitric oxide may be depleted. In spite of a complex system of regulation (Rockey, 2003) and increased whole-body NO production in patients with cirrhosis (Vallance \& Moncada, 1991), hepatic NO synthesis is, paradoxically, thought to be reduced in the diseased liver (Sarela et al. 1999). Moreover, since impaired liver function decreases the hepatic breakdown of ADMA, liver failure results in increased concentrations of ADMA (Nijveldt et $a$ l. 2003a,b), thereby potentially limiting hepatic NO production further.

Furthermore, NO may be important following the observation of increased extracellular levels of brain glutamate in experimental liver failure (de Knegt et al. 1994), since NO can increase glutamate release from the synaptic cleft (Katchman \& Hershkowitz, 1997). Astrocytes may use increased amounts of arginine in liver failure, as astrocytes show increased arginine uptake and NOS expression when cultured in the presence of ammonia (Hazell \& Norenberg, 1998). It is possible that an increased arginine uptake is a compensatory mechanism by which glutamate stores can be replenished through an arginine-glutamate shunt, following ammonia-induced increases in glutamine production. Moreover, as arginine is an important intermediate in the urea cycle, arginine depletion can further compound increases in brain ammonia.

During liver transplantation, high amounts of arginase are released from the graft after hepatic reperfusion, thereby decreasing the availability of arginine (Bzeizi et al. 1997; Yagnik et al. 2002) and its product NO (Ikemoto et al. 1998). The pulmonary hypertension and the reduced hepatic blood flow found during the immediate reperfusion period after orthotopic liver transplantation are possibly related to the decreased arginine availability.

\section{Wound healing}

Wound healing is a complex process involving three subsequent phases; inflammation, proliferation and remodulation. During the inflammatory phase neutrophils, macrophages and lymphocytes clean the wound area from foreign material and prevent further bacterial colonisation. Proliferation is characterised by multiple reparative cells, mainly fibroblasts. They form the structural proteins for a new matrix. In this phase endothelial and epithelial cell proliferation occur, leading to angiogenesis and epithelialisation. During remodulation, the wound contracts to form a mature scar. The newly formed collagen is reorganised, resulting in increasing wound strength.

In mice and rats with acute wounds, arginine was shown to be involved in wound healing via two metabolic pathways (Albina et al. 1990; Schaffer et al. 1997; Efron \& Barbul, 2000; Lee et al. 2001). The first pathway was mainly active in the first $3 \mathrm{~d}$ and was catalysed by NOS2, with citrulline and NO as endproducts. After a few days a shift to the second pathway occurred, catalysed by arginase, which converted arginine into ornithine and urea. Ornithine is a precursor for collagen synthesis and cell growth. This sequence of events suggests that during the initial phase of wound healing, angiogenesis is stimulated through NO synthesis, whereas at a later stage arginase-mediated ornithine production facilitates collagen synthesis.

Arginine metabolism. Schaffer et al. (1997) and Lee et al. (2001) demonstrated the consumption of arginine during acute wound healing. In their studies, arginine levels in the wound fluid of mice were not detectable, whereas endproducts of arginine metabolism were increased, thus suggesting the local use of arginine in wounds.

One of the products of arginine is ornithine, in itself a precursor for collagen synthesis. Studies with NOS2knockout mice supplied with dietary ornithine show increased wound breaking strength and collagen deposition (Shi et al. 2000, 2001).

Nitric oxide production. In experimental studies with mice, Witte, Barbul and Schaffer demonstrated the essential role of NO in wound healing by showing that NOS2knockout mice had delayed wound healing (Witte \& Barbul, 2002) and NO inhibitors diminished wound collagen formation (Schaffer et al. 1999). In tendon healing, Murrell et al. (1997) showed an increase in NOS activity during healing. Furthermore, when NOS2 was inhibited, tendon healing was inhibited. Similar results were found concerning NO and fracture healing (Diwan et al. 2000). In experiments with NOS3-deficient mice, wound closure was delayed, tensile strength decreased and endothelial cell sprouting reduced (Lee et al. 1999). This up regulation of the enzymes involved in the NO pathway suggests an increased need for arginine in wound healing, as arginine is the sole precursor for NO.

Why arginine or nitric oxide may be depleted. The availability of arginine is one of the rate-limiting factors of cellular NO production (Hallemeesch et al. 2002b). Wound-repair cells, such as macrophages, fibroblasts, endothelial cells and keratinocytes, also depend on extracellular arginine concentration for their NO synthesis (Jalkanen et al. 1982; Norris et al. 1995). Therefore, it is important that the wound is supplied with sufficient arginine. Reasons for arginine depletion can be (1) an insufficient supply of arginine or (2) an increased use of arginine.

Concerning the first point, diets deficient in arginine are associated with poor wound healing and poor growth in rats (Seifter et al. 1978; Nirgiotis et al. 1991). In human patients it is common knowledge that protein deficiency or malnutrition impairs wound healing, and although arginine supplementation increases wound collagen deposition in 
human patients, little is known about the role of arginine depletion in human wound healing. Our own recent data suggest that chronic wound healing is associated with decreased plasma arginine levels (IBJG Debats, D Booi, NEP Deutz, WA Burman, WD Boeckx and RRWJ Van der Hulst, unpublished results).

Regarding the second reason, NO synthesis is increased during wound healing as shown by Albina et al. (1990). The activity might become so high that the supply of arginine may become limiting. Furthermore, arginine can be competitively metabolised by arginase. An enhanced expression of arginase is seen in wound-derived fibroblasts, diabetes-impaired healing and psoriatic skin lesions (Witte et al. 2002a; Kampfer et al. 2003; Weller, 2003). It is hypothesised that arginine in wounds is depleted by extracellular arginase which is released during macrophage cell death (Albina et al. 1988).

\section{L-Arginine supplementation in disease}

Since a large part (40\%) of enteral arginine is degraded during absorption and at least $85 \%$ of the arginine that enters the portal vein is delivered to the liver, intraveneous arginine administration may be more effective in providing arginine to extra-gastrointestinal tissue (Flynn et al. 2002). Both intravenous and oral L-arginine administration in healthy human subjects increased plasma arginine levels and significantly reduced blood pressure and total peripheral resistance, with increases in urinary nitrate and cyclic GMP excretion (Bode-Boger et al. 1998). This indicates that the vascular effects of L-arginine are closely correlated to its plasma concentrations (Bode-Boger et al. 1998), even in subjects without an inflammatory response where increases in NOS2 are not expected.

\section{Sepsis}

Only one human study in septic patients provides data on the supplementation of L-arginine as a monotherapy and demonstrated transient systemic and pulmonary vasodilatory actions of L-arginine- $\mathrm{HCl}(200 \mathrm{mg}$ intravenous bolus $/ \mathrm{kg}$ ) at $1 \mathrm{~min}$ after administration, without adverse effects (Lorente et al. 1993a).

In animal studies, beneficial effects of L-arginine administration have been shown on the immune response (Moffat et al. 1996; Calkins et al. 2001; Yeh et al. 2002). Besides this, L-arginine administration further stimulated alveolar and intravascular NO release in the lung, with a slight limitation of the increase in pulmonary arterial pressure and concomitant oedema formation (Schutte et al. 1998). LArginine treatment produced systemic vasodilatation in normal sheep, whereas both systemic and pulmonary vasodilatation was observed in septic animals in the later phase of sepsis (Lorente et al. 1993b, 1999). However, data on survival are not uniform (Gonce et al. 1990; Gianotti et al. 1993; Yeh et al. 2002).

In a hyperdynamic pig model of sepsis it was suggested that L-arginine administration reduces the hepatic response to tissue injury and inflammation (Bruins et al. 2002b). NO production on the whole-body level and in the portaldrained viscera, liver and kidneys was up regulated (Bruins et al. 2002c), and net uptake of arginine in hindquarters, the portal-drained viscera, liver and kidneys was observed (Bruins et al. 2002c). Suggested adverse effects of L-arginine supplementation are hypotension, electrolyte imbalance ( $\mathrm{Cl}$ and $\mathrm{K}$ ), hypoglycaemia (due to stimulated insulin release), and increased urea levels (Boger \& Bode-Boger, 2001). However, these symptoms are mainly based on intravenous bolus infusions of L-arginine- $\mathrm{HCl}(30 \mathrm{~g} \mathrm{~L}$-arginine- $\mathrm{HCl}$ in $30 \mathrm{~min}$ ). In the pigs with hyperdynamic sepsis no deleterious systemic side effects of prolonged intravenous L-arginine infusion were observed with only minor haemodynamic changes (tendency for decreased mean arterial pressure, and increased cardiac index; Bruins et al. $2002 c$ ), while the deleterious increase in pulmonary arterial pressure that normally occurs in sepsis was prohibited (M Poeze, M Bruins, G Ramsay, WH Lamers and NEP Deutz, unpublished results). Preliminary data on continuous Larginine infusion in septic-shock patients confirm these results, as hypotension and changes in $\mathrm{Cl}$ and $\mathrm{K}$ levels did not occur (YC Luiking, M Hendrikx, M Poeze, P Breedveld, PW de Feiter, F Rubulotta, CHC Dejong, G Ramsay and NEP Deutz, unpublished results). This suggests that the protocol of L-arginine administration is important, and continuous infusion seems to be preferred.

\section{Cancer}

Tumour growth. Many studies on L-arginine supplementation and tumour growth have been conducted, leading to two opposite hypotheses; that L-arginine either stimulates or inhibits tumour growth. For example, L-arginine supplementation, either intravenously or enterally, retarded (Takeda et al. 1975; Milner \& Stepanovich, 1979; Tachibana et al. 1985; Reynolds et al. 1990; Lubec et al. 1996; Edwards et al. 1997; Millis et al. 1998; Szende et al. 2001), enhanced (Yeatman et al. 1991; Szende et al. 2001) or did not change (Oka et al. 1993, 1994) in vivo tumour growth in rodents compared with isonitrogenous control supplements. The limitation of these animal tumour models lies in the fact that most of these models are highly immunogenic, while most human cancers are not. The impact of protein depletion on tumour biology appears to relate to how well the tumour is recognised by the host. This is determined by the expression of tumour-associated antigens, which can be recognised as foreign by an intact host immune system. Protein malnutrition theoretically favours the growth of antigenic tumours by depressing immune responses. This is illustrated by a study of Reynolds et al. (1988b), in which mice bearing an immunogenic tumour showed decreased tumour growth and prolonged survival after arginine supplementation, while in mice with non-immunogenic tumours, growth was increased.

Mortality. Regarding survival, few controlled in vivo animal studies have been conducted. Compared with glycine as an isonitrogenous control, $1 \%$ enteral L-arginine supplementation in tumour-bearing mice prolonged host survival (Reynolds et al. 1990). Furthermore, Novaes et al. (2000) showed that tumour-bearing rats receiving $\mathrm{L}$-arginine enterally had less metastases than rats receiving glycine as the isonitrogenous control. Moreover, it has been demonstrated 
that an L-arginine-enriched parenteral solution increased muscle protein synthesis (Oka et al. 1994) and decreased total $\mathrm{N}$ release (Oka et al. 1993) in rats with Yoshida sarcoma. Whether these improvements in protein turnover are related to higher survival remains to be established.

Immunostimulation. In tumour-bearing mice, L-arginine was one of the first nutritional supplements to be tested for potential immune-stimulating effects (Rettura et al. 1979). An increased thymic weight and cellularity was observed, although no isonitrogenous control supplement was used. Repeated experiments with proper control groups confirmed that L-arginine indeed has immune-stimulating properties in tumour-bearing animals, such as an enhanced lymphocyte cytotoxicity (Reynolds et al. 1988a; Lieberman et al. 1992) and natural killer cell activity (Reynolds et al. $1988 a)$.

Patient studies. Enteral L-arginine supplementation for $3 \mathrm{~d}$ to breast cancer patients enhanced the cytotoxicity of natural killer and lymphokine-activated killer cells (Brittenden et al. 1994b), which are thought to be involved in tumour cytotoxicity. Similarly, $3 \mathrm{~d}$ of L-arginine supplementation to patients with colorectal cancer altered the spectrum of tumour-infiltrating lymphocytes (Heys et al. 1997), which have anti-tumour properties. It should be noticed that in both studies, no control supplement was administered. Patients with breast cancer receiving an enteral diet supplemented with arginine for $3 \mathrm{~d}$ had higher protein synthesis in tumours compared with patients receiving the enteral diet without supplementation (Park et al. 1992). Again, no control amino acid was administered, so conclusions drawn from these studies must be interpreted with caution.

Effects during chemotherapy. L-Arginine supplementation has also been used in trials with breast cancer patients receiving chemotherapy. Human breast cancer is considered to be a non-immunogenic tumour. Because in an animal study with non-immunogenic tumours L-arginine stimulated tumour growth (Reynolds et al. 1988b), the use of immunotherapy in breast cancer is controversial. Still, $3 \mathrm{~d}$ of L-arginine supplementation before each course of chemotherapy was reported to diminish and delay the onset of immunosuppression and to stimulate natural killer and lymphokine-activated killer cells (Brittenden et al. 1994a). However, no control amino acid supplement was used and no information on tumour growth was reported.

Post-operative effects. Several authors have studied the effect of L-arginine on post-operative immune response in cancer patients. Daly et al. (1988) compared post-operative enteral supplementation of L-arginine with that of isonitrogenous glycine, and concluded that L-arginine enhanced the peripheral lymphocyte response and increased the number of CD4+ T-cells in gastrointestinal cancer patients. In post-operative head and neck cancer patients fed an enteral diet supplemented with L-arginine, lymphocyte count was increased compared with an isoenergetic and isonitrogenous control (Riso et al. 2000). Also, patients with gastrointestinal malignancies on a diet supplemented with
L-arginine had higher numbers of circulating T-cells on post-operative day 7 compared with an isoenergetic and isonitrogenous control diet (Sigal et al. 1992). In contrast, on the first post-operative day, no effect of pre-operative isoenergetic and isonitrogenous enteral arginine supplementation was seen on lymphocyte proliferation or monocyte function in gastrointestinal cancer patients (McCarter et al. 1998).

Until now, only two clinical studies with L-arginine as monotherapy and with isonitrogenous and isoenergetic controls have been conducted in cancer patients, both in malnourished head and neck cancer patients undergoing surgery. Riso et al. (2000) concluded that a post-operative enteral diet supplemented with L-arginine for $4 \mathrm{~d}$ significantly reduced post-operative infections and length of stay. In the study from van Bokhorst-de van der Schueren et al. (2001) a trend $(P=0 \cdot 15)$ toward better survival was seen after pre-operative enteral L-arginine supplementation for 9 d. However, the required sample size was calculated to be thirty-nine patients, while only fifteen to seventeen patients per group could be included. Therefore, the observed results could have important significance and deserve further study.

\section{Liver failure}

Cirrhosis. The clinical application of L-arginine supplementation in liver disease is limited by the lack of systematic investigations to characterise the circulatory effects following L-arginine administration. However, it has been shown that arginine infusions induce diuresis and natriuresis in cirrhotic patients with ascites, accompanied by increased urinary $\mathrm{NO}_{\mathrm{x}}$, suggesting a possible effect on regional microcirculatory beds (Tajiri et al. 1995).

Ischaemia-reperfusion injury. There are no fully published human studies describing the role of L-arginine supplementation in preventing ischaemia-reperfusion injury. A study in pigs demonstrated the protective effect of L-arginine on hepatic lipoperoxidation and liver morphology in a model of warm ischaemia-reperfusion injury (Burra et al. 2001). It was observed that $30 \mathrm{~min}$ after reperfusion, liver malondialdehyde, sinusoidal congestion, necrosis, and apoptosis were significantly lower in the arginine group. On post-operative day 7, tissue malondialdehyde decreased, while plasma $\mathrm{NO}_{\mathrm{x}}$ and hepatocyte glycogen content were increased in the L-arginine group.

Furthermore, oral L-arginine supplementation in an animal model of liver failure demonstrated a benefit in terms of hepatic inflammatory changes and bacterial translocation (Adawi et al. 1996).

The benefits of systemic supplementation, however, must be weighed against potential deleterious effects such as compounding low peripheral vascular resistance through the promotion of systemic NO generation, and thereby further decreasing organ blood flow.

\section{Wound healing}

In rats, $300 \mathrm{mg}$ L-arginine/kg intraperitoneally per $\mathrm{d}$ enhanced wound tensile strength, hydroxyproline concentra- 
tions and collagen accumulation. In addition, it decreased neutrophil counts and adhesivity (Canturk et al. 2001). In NOS2-knockout mice, NOS2 was shown to be an important mediator of the positive effects of L-arginine supplementation on wound breaking strength and hydroxyproline content (Shi et al. 2000). Arbss et al. (2000) studied the effects of high arginine plasma levels on early integration of biocompatible mesh grafts in the rat abdominal wall. They found enhanced cell accumulation, formation of new vessels, fibroblast proliferation and type III collagen deposition in the L-arginine-supplemented group. In an experimental model for ileitis, ulcer healing was enhanced in rats supplied with diets containing $5 \%$ L-arginine (Sukumar et al. 1997). Healing of colonic anastomosis in rats on post-operative day 6 was enhanced when rats were fed a peri-operatively L-arginine-enriched diet (Shashidharan et al. 1999).

L-Arginine supplementation improved wound immunecell function in mice, demonstrated by decreased proinflammatory IL-1 $\beta$, IL-6 and increased anti-inflammatory IL-10 (Angele et al. 2002).

Angiogenesis. Angele et al. (2002) demonstrated increased microcirculation after L-arginine supplementation in mice with depressed skin and muscle blood flow after haemorrhage. Enteral L-arginine supplementation in a rabbit ischaemic hind-limb model stimulated angiogenesis, as shown by a marked increase in capillary density and enhanced collateral vessel development (Murohara et al. 1998). NOS3 was essential for angiogenesis in ischaemic tissues in this model.

Pathological wound healing. Diabetes is characterised by an NO-deficient state at the wound site. In diabetic rats, enteral L-arginine supplementation increased wound breaking strength. At the same time, plasma arginine and $\mathrm{NO}_{\mathrm{x}}$ levels were increased, while wound fluid levels of arginine and ornithine remained unaffected (Witte et al. 2002c). This suggests that the exogenously provided L-arginine is metabolised to NO by NOS2. In accordance, supplementing the NO donor molsidomine to these rats increased wound breaking strength and wound-healing parameters such as the hydroxyproline content and matrix metalloproteinase-a (MMP-2) activity and the urinary $\mathrm{NO}_{3}$ excretion. It also decreased collagen I and III gene expression and arginase activity (Witte et al. 2002b).

Human studies. Only a few human studies have investigated the effect of L-arginine as the single pharmaconutrient on wound healing. Kirk et al. (1993) supplied thirty healthy elderly human volunteers with $17 \mathrm{~g}$ oral L-arginine/d and found improved serum insulin-like growth factor-1, enhanced hydroxyproline and total protein content deposition in subcutaneously placed catheters. It did not shorten the time to complete epithelialisation of skin defects of $2 \mathrm{~cm}^{2}$. Barbul et al. (1990) supplied L-arginine to thirty-six young healthy human subjects, divided into three groups, who received either 17 or $25 \mathrm{~g}$ oral L-arginine or placebo for 2 weeks. Both L-arginine-supplemented groups displayed enhanced hydroxyproline accumulation in subcutaneously placed catheters. Besides this, lymphocyte immune reactivity was enhanced.
So far, no human studies on the effect of L-arginine on angiogenesis in wound healing have been published.

\section{Conclusion and future directions}

First, it can only be concluded that up to now, monotherapy with L-arginine has scarcely been studied in the various disease states described in the present review. However, the numerous studies using immunonutrition containing L-arginine amongst other nutrients have led to negative advice on clinical L-arginine supplementation. Again, it must be emphasised that from studies using mixtures of pharmaconutrients, no valid conclusions can be drawn with regard to the separate effects of the contents. Therefore, from a scientific point of view, more studies using L-arginine as a monotherapy in a controlled setup are needed before definite conclusions can be drawn.

Second, only limited information is available on in vivo arginine-NO metabolism in both health and disease. Since both arginine and NO appear to affect various tissues in different ways, research into (inter)-organ physiology would be valuable. Because inter-organ studies are only possible to a limited extent in human volunteers and patients for ethical reasons, animal models will be a necessary source of information. Thereupon, results can partly be confirmed in human subjects. Moreover, without knowledge of the pathophysiological changes in arginine metabolism, it is almost impossible to determine the optimal timing, way of administration (intravenously or enterally) and amount of $\mathrm{L}$-arginine to be supplemented. As a result, up to now, protocols for L-arginine administration have been mere guesses and may not result in optimal results of L-arginine supplementation. Next, other mechanisms that may affect arginine availability and thereby affect NO production should be studied more closely, including arginase activity, de novo arginine synthesis, oxidation of arginine, and the presence of endogenous arginine analogues. Also, studies may focus more on the pathophysiological consequences of decreased NOS1 and NOS3 instead of on increased NOS2.

Finally, the optimal source to supply L-arginine in diseases remains to be determined. Instead of L-arginine itself, this may be glutamine or citrulline, since both these amino acids can be converted to arginine in the body.

\section{References}

Adamik B, Kubler-Kielb J, Golebiowska B, Gamian A \& Kubler A (2000) Effect of sepsis and cardiac surgery with cardiopulmonary bypass on plasma level of nitric oxide metabolites, neopterin, and procalcitonin: correlation with mortality and postoperative complications. Intensive Care Medicine 26, 1259-1267.

Adawi D, Kasravi FB, Molin G \& Jeppsson B (1996) Oral arginine supplementation in acute liver injury. Nutrition 12, 529-533.

Aggarwal S, Kang Y, Freeman JA, Fortunato FL \& Pinsky MR (1987) Postreperfusion syndrome: cardiovascular collapse following hepatic reperfusion during liver transplantation. Transplantation Proceedings 19, 54-55.

Aggarwal S, Kang Y, Freeman JA, Fortunato FL Jr \& Pinsky MR (1993) Postreperfusion syndrome: hypotension after reperfusion of the transplanted liver. Journal of Critical Care 8 , $154-160$. 
Albina JE, Mills CD, Barbul A, Thirkill CE, Henry WL Jr, Mastrofrancesco B \& Caldwell MD (1988) Arginine metabolism in wounds. American Journal of Physiology 254, E459-E467.

Albina JE, Mills CD, Henry WL Jr \& Caldwell MD (1990) Temporal expression of different pathways of L-arginine metabolism in healing wounds. Journal of Immunology 144, 3877-3880.

Angele MK, Nitsch SM, Hatz RA, Angele P, Hernandez-Richter T, Wichmann MW, Chaudry IH \& Schildberg FW (2002) LArginine: a unique amino acid for improving depressed wound immune function following hemorrhage. European Surgical Research 34, 53-60.

Angus DC, Linde-Zwirble WT, Lidicker J, Clermont G, Carcillo J \& Pinsky MR (2001) Epidemiology of severe sepsis in the United States: analysis of incidence, outcome, and associated costs of care. Critical Care Medicine 29, 1303-1310.

Annane D, Sanquer S, Sebille V, Faye A, Djuranovic D, Raphael JC, Gajdos P \& Bellissant E (2000) Compartmentalised inducible nitric-oxide synthase activity in septic shock. Lancet 355, 1143-1148.

Arbss MA, Ferrando JM, Vidal J, Quiles MT, Huguet P, Castells J, Segarra A, Armengol M \& Schwartz S (2000) Early effects of exogenous arginine after the implantation of prosthetic material into the rat abdominal wall. Life Sciences 67, 2493-2512.

Argaman Z, Young VR, Noviski N, Castillo-Rosas L, Lu XM, Zurakowski D, Cooper M, Davison C, Tharakan JF, Ajami A \& Castillo L (2003) Arginine and nitric oxide metabolism in critically ill septic pediatric patients. Critical Care Medicine 31, 591-597.

Arnal JF, Dinh-Xuan AT, Pueyo M, Darblade B \& Rami J (1999) Endothelium-derived nitric oxide and vascular physiology and pathology. Cellular and Molecular Life Sciences 55, 1078-1087.

Baltaci S, Orhan D, Gogus C, Turkolmez K, Tulunay O \& Gogus O (2001) Inducible nitric oxide synthase expression in benign prostatic hyperplasia, low- and high-grade prostatic intraepithelial neoplasia and prostatic carcinoma. BJU International 88, $100-103$.

Bankir L (1996) Urea and the Kidney. Philadelphia, PA: W.B. Saunders Company.

Barbul A (1990) Arginine and immune function. Nutrition 6, 53-58; discussion 59-62.

Barbul A, Lazarou SA, Efron DT, Wasserkrug HL \& Efron G (1990) Arginine enhances wound healing and lymphocyte immune responses in humans. Surgery 108, 331-336; discussion 336-337.

Beach PK, Spain DA, Kawabe T, Harris PD \& Garrison RN (2001) Sepsis increases NOS-2 activity and decreases nonNOS-mediated acetylcholine-induced dilation in rat aorta. Journal of Surgical Research 96, 17-22.

Bode-Boger SM, Boger RH, Galland A, Tsikas D \& Frolich JC (1998) L-Arginine-induced vasodilation in healthy humans: pharmacokinetic-pharmacodynamic relationship. British Journal of Clinical Pharmacology 46, 489-497.

Boger RH \& Bode-Boger SM (2001) The clinical pharmacology of L-arginine. Annual Review of Pharmacology and Toxicology 41, 79-99.

Boros P, Tarcsafalvi A, Wang L, Megyesi J, Liu J \& Miller CM (2001) Intrahepatic expression and release of vascular endothelial growth factor following orthotopic liver transplantation in the rat. Transplantation 72, 805-811.

Braillon A, Cales P, Valla D, Gaudy D, Geoffroy P \& Lebrec D (1986) Influence of the degree of liver failure on systemic and splanchnic haemodynamics and on response to propranolol in patients with cirrhosis. Gut 27, 1204-1209.

Brealey D, Brand M, Hargreaves I, Heales S, Land J, Smolenski
R, Davies NA, Cooper CE \& Singer M (2002) Association between mitochondrial dysfunction and severity and outcome of septic shock. Lancet 360, 219-223.

Brittenden J, Heys SD, Ross J, Park KG \& Eremin O (1994a) Natural cytotoxicity in breast cancer patients receiving neoadjuvant chemotherapy: effects of L-arginine supplementation. European Journal of Surgical Oncology 20, 467-472.

Brittenden J, Park KG, Heys SD, Ross C, Ashby J, Ah-See A \& Eremin O (1994b) L-Arginine stimulates host defenses in patients with breast cancer. Surgery 115, 205-212.

Bronte V, Serafini P, Mazzoni A, Segal DM \& Zanovello P (2003) L-Arginine metabolism in myeloid cells controls T-lymphocyte functions. Trends in Immunology 24, 302-306.

Brosnan JT (1987) The 1986 Borden Award Lecture. The role of the kidney in amino acid metabolism and nutrition. Canadian Journal of Physiology and Pharmacology 65, 2355-2362.

Bruins MJ, Lamers WH, Meijer AJ, Soeters PB \& Deutz NE (2002a) In vivo measurement of nitric oxide production in porcine gut, liver and muscle during hyperdynamic endotoxaemia. British Journal of Pharmacology 137, 1225-1236.

Bruins MJ, Soeters PB, Lamers WH \& Deutz NE (2002b) LArginine supplementation in pigs decreases liver protein turnover and increases hindquarter protein turnover both during and after endotoxemia. American Journal of Clinical Nutrition 75, 1031-1044.

Bruins MJ, Soeters PB, Lamers WH, Meijer AJ \& Deutz NEP (2002c) L-Arginine supplementation in hyperdynamic endotoxemic pigs: effect on nitric oxide synthesis by the different organs. Critical Care Medicine 30, 508-517.

Bune AJ, Shergill JK, Cammack R \& Cook HT (1995) L-Arginine depletion by arginase reduces nitric oxide production in endotoxic shock: an electron paramagnetic resonance study. FEBS Letters 366, 127-130.

Burra P, Chirizzi L, Cardin R, Cadrobbi R, Baldan N, Calabrese F, Pettenazzo E, Calo L, Plebani M \& Rigotti P (2001) Warm hepatic ischemia in pigs: effects of L-arginine and oligotide treatment. Journal of Investigative Surgery 14, 303-312.

Bzeizi KI, Jalan R, Henderson N, Thomas HW, Lee A \& Hayes PC (1997) Influence of cyclic guanosine monophosphate changes on hemodynamics after reperfusion in liver transplantation. Transplantation 63, 403-406.

Calkins CM, Bensard DD, Heimbach JK, Meng X, Shames BD, Pulido EJ \& McIntyre RC Jr (2001) L-Arginine attenuates lipopolysaccharide-induced lung chemokine production. American Journal of Physiology 280, L400-L408.

Canturk NZ, Vural B, Canturk Z, Esen N, Vural S, Solakoglu S \& Kirkal G (2001) The role of L-arginine and neutrophils on incisional wound healing. European Journal of Emergency Medicine 8, 311-315.

Castillo L, Beaumier L, Ajami AM \& Young VR (1996) Whole body nitric oxide synthesis in healthy men determined from $\left[{ }^{15} \mathrm{~N}\right]$ arginine-to- $\left[{ }^{15} \mathrm{~N}\right]$ citrulline labeling. Proceedings of the National Academy of Sciences USA 93, 11460-11465.

Castillo L, Sanchez M, Vogt J, Chapman TE, DeRojas-Walker TC, Tannenbaum SR, Ajami AM \& Young VR (1995) Plasma arginine, citrulline, and ornithine kinetics in adults, with observations on nitric oxide synthesis. American Journal of Physiology 268, E360-E367.

Chamuleau RAFM, Deutz NEP, de Haan JG \& van Gool J (1987) Correlation between electroencephalographic and biochemical indices in acute hepatic encephalopathy in rats. Journal of Hepatology 4, 299-306.

Chen K, Inoue M, Wasa M, Fukuzawa M, Kamata S \& Okada A (1997) Expression of endothelial constitutive nitric oxide synthase mRNA in gastrointestinal mucosa and its downregulation by endotoxin. Life Sciences 61, 1323-1329.

Choe W, Kim S, Hwang TS \& Lee SS (2003) Expression of 
inducible nitric oxide synthase in thyroid neoplasms: immunohistochemical and molecular analysis. Pathology International $\mathbf{5 3}, 434-439$.

Cianchi F, Cortesini C, Fantappie O, Messerini L, Schiavone N, Vannacci A, Nistri S, Sardi I, Baroni G, Marzocca C, Perna F, Mazzanti R, Bechi P \& Masini E (2003) Inducible nitric oxide synthase expression in human colorectal cancer: correlation with tumor angiogenesis. American Journal of Pathology 162, 793-801.

Clavien PA, Camargo CA Jr, Gorczynski R, Washington MK, Levy GA, Langer B \& Greig PD (1996) Acute reactant cytokines and neutrophil adhesion after warm ischemia in cirrhotic and noncirrhotic human livers. Hepatology 23, 1456-1463.

Cobbs CS, Brenman JE, Aldape KD, Bredt DS \& Israel MA (1995) Expression of nitric oxide synthase in human central nervous system tumors. Cancer Research 55, 727-730.

Colletti LM, Kunkel SL, Walz A, Burdick MD, Kunkel RG, Wilke CA \& Strieter RM (1995) Chemokine expression during hepatic ischemia/reperfusion-induced lung injury in the rat. The role of epithelial neutrophil activating protein. Journal of Clinical Investigations 95, 134-141.

Crenn P, Coudray-Lucas C, Cynober L \& Messing B (1998) Postabsorptive plasma citrulline concentration: a marker of intestinal failure in humans. Transplantation Proceedings 30, 2528.

Crenn P, Coudray-Lucas C, Thuillier F, Cynober L \& Messing B (2000) Postabsorptive plasma citrulline concentration is a marker of absorptive enterocyte mass and intestinal failure in humans. Gastroenterology 119, 1496-1505.

Crenn P, Vahedi K, Lavergne-Slove A, Cynober L, Matuchansky C \& Messing B (2003) Plasma citrulline: a marker of enterocyte mass in villous atrophy-associated small bowel disease. Gastroenterology 124, 1210-1219.

Cynober L (1994) Can arginine and ornithine support gut functions? Gut 35, Suppl. 1, S42-S45.

Cynober L, Le Boucher J \& Vasson M-P (1995) Arginine metabolism in mammals. Journal of Nutritional Biochemistry 6, 402-403.

Daly JM, Reynolds J, Thom A, Kinsley L, Dietrick-Gallagher M, Shou J \& Ruggieri B (1988) Immune and metabolic effects of arginine in the surgical patient. Annals of Surgery 208, 512-523.

De Backer D, Creteur J, Preiser JC, Dubois MJ \& Vincent JL (2002) Microvascular blood flow is altered in patients with sepsis. American Journal of Respiratory and Critical Care Medicine 166, 98-104.

Dedio J, Konig P, Wohlfart P, Schroeder C, Kummer W \& MullerEsterl W (2001) NOSIP, a novel modulator of endothelial nitric oxide synthase activity. FASEB Journal 15, 79-89.

Dejong CHC, Deutz NEP \& Soeters PB (1993a) Intestinal glutamine and ammonia metabolism during chronic hyperammonaemia induced by liver insufficiency. Gut 34, 1112-1119.

Dejong CHC, Deutz NEP \& Soeters PB (1993b) Metabolic adaptation of the kidney to hyperammonemia during chronic liver insufficiency in the rat. Hepatology 18, 890-902.

Dejong CHC, Welters CFM, Deutz NEP, Heineman E \& Soeters PB (1998) Renal arginine metabolism in fasted rats with subacute short bowel syndrome. Clinical Science 95, 409-418.

de Knegt RJ, Schalm SW, van der Rijt CC, Fekkes D, Dalm E \& Hekking-Weyma I (1994) Extracellular brain glutamate during acute liver failure and during acute hyperammonemia simulating acute liver failure: an experimental study based on in vivo brain dialysis. Journal of Hepatology 20, 19-26.

Deutz NEP, Bruins MJ \& Soeters PB (1998) Infusion of soy and casein protein meals affects interorgan amino acid metabolism and urea kinetics differently in pigs. Journal of Nutrition 128, $2435-2445$.
Deutz NEP, Dejong CHC, Athanasas G \& Soeters PB (1992) Partial enterectomy in the rat does not diminish muscle glutamine production. Metabolism 41, 1343-1350.

de Werra I, Jaccard C, Corradin SB, Chiolero R, Yersin B, Gallati $\mathrm{H}$, Assicot M, Bohuon C, Baumgartner JD, Glauser MP \& Heumann D (1997) Cytokines, nitrite/nitrate, soluble tumor necrosis factor receptors, and procalcitonin concentrations: comparisons in patients with septic shock, cardiogenic shock, and bacterial pneumonia. Critical Care Medicine 25, 607-613.

Dhanakoti SN, Brosnan JT, Herzberg GR \& Brosnan ME (1990) Renal arginine synthesis: studies in vitro and in vivo. American Journal of Physiology 259, E437-E442.

Dickinson E, Tuncer R, Nadler E, Boyle P, Alber S, Watkins S \& Ford H (1999) NOx, a novel nitric oxide scavenger, reduces bacterial translocation in rats after endotoxin challenge. American Journal of Physiology 277, G1281-G1287.

Diwan AD, Wang MX, Jang D, Zhu W \& Murrell GA (2000) Nitric oxide modulates fracture healing. Journal of Bone and Mineral Research 15, 342-351.

Edwards PD, Topping D, Kontaridis MI, Moldawer LL, Copeland EM III \& Lind DS (1997) Arginine-enhanced enteral nutrition augments the growth of a nitric oxide-producing tumor. Journal of Parenteral and Enteral Nutrition 21, 215-219.

Efron D \& Barbul A (2000) Role of arginine in immunonutrition. Journal of Gastroenterology 35, Suppl. 12, 20-23.

Endo S, Inada K, Nakae H, Arakawa N, Takakuwa T, Yamada Y, Shimamura T, Suzuki T, Taniguchi S \& Yoshida M (1996) Nitrite/nitrate oxide (NOx) and cytokine levels in patients with septic shock. Research Communications in Molecular Pathology and Pharmacology 91, 347-356.

Evans T, Carpenter A, Kinderman H \& Cohen J (1993) Evidence of increased nitric oxide production in patients with the sepsis syndrome. Circulatory Shock 41, 77-81.

Flynn NE, Meininger CJ, Haynes TE \& Wu G (2002) The metabolic basis of arginine nutrition and pharmacotherapy. Biomedicine and Pharmacotherapy 56, 427-438.

Freund H, Atamian S, Holroyde J \& Fischer JE (1979) Plasma amino acids as predictors of the severity and outcome of sepsis. Annals of Surgery 190, 571-576.

Gallo O, Schiavone N, Papucci L, Sardi I, Magnelli L, Franchi A, Masini E \& Capaccioli S (2003) Down-regulation of nitric oxide synthase- 2 and cyclooxygenase-2 pathways by P53 in squamous cell carcinoma. American Journal of Pathology 163, 723-732.

Garcia-Martinez C, Llovera M, Lopez-Soriano FJ \& Argiles JM (1993) The effects of endotoxin administration on blood amino acid concentrations: similarities with sepsis. Cellular and Molecular Biology 39, 537-542.

Gerlach J, Jorres A, Schon M, Nohr R, Berger A, Spatkowski G, Smith MD \& Neuhaus P (1997) Systemic liberation of interleukin- 8 in the perioperative phase of liver transplantation. Transplant International 10, 401-404.

Gewaltig MT \& Kojda G (2002) Vasoprotection by nitric oxide: mechanisms and therapeutic potential. Cardiovascular Research 55, 250-260.

Gianotti L, Alexander JW, Pyles T \& Fukushima R (1993) Arginine-supplemented diets improve survival in gut-derived sepsis and peritonitis by modulating bacterial clearance. The role of nitric oxide. Annals of Surgery 217, 644-653; discussion 653-654

Glass RE, Goode AW, Houghton BJ \& Rowell LW (1986) Plasma arginine in cancer of the gastrointestinal tract: effect of surgical treatment. Gut 27, 844-848.

Gokmen SS, Aygit AC, Ayhan MS, Yorulmaz F \& Gulen S (2001) Significance of arginase and ornithine in malignant tumors of the human skin. Journal of Laboratory and Clinical Medicine 137, 340-344.

Gomez-Jimenez J, Salgado A, Mourelle M, Martin MC, Segura 
RM, Peracaula R \& Moncada S (1995) L-Arginine: nitric oxide pathway in endotoxemia and human septic shock. Critical Care Medicine 23, 253-258.

Gonce SJ, Peck MD, Alexander JW \& Miskell PW (1990) Arginine supplementation and its effect on established peritonitis in guinea pigs. Journal of Parenteral and Enteral Nutrition 14, 237-244.

Goode HF, Webster NR, Howdle PD, Leek JP, Lodge JP, Sadek SA \& Walker BE (1994) Reperfusion injury, antioxidants and hemodynamics during orthotopic liver transplantation. Hepatology 19, 354-359.

Groeneveld AB, Hartemink KJ, de Groot MC, Visser J \& Thijs LG (1999) Circulating endothelin and nitrate-nitrite relate to hemodynamic and metabolic variables in human septic shock. Shock 11, 160-166.

Groeneveld PH, Kwappenberg KM, Langermans JA, Nibbering PH \& Curtis L (1996) Nitric oxide (NO) production correlates with renal insufficiency and multiple organ dysfunction syndrome in severe sepsis. Intensive Care Medicine 22, 1197-1202.

Groeneveld PH, Kwappenberg KM, Langermans JA, Nibbering PH \& Curtis L (1997) Relation between pro- and anti-inflammatory cytokines and the production of nitric oxide (NO) in severe sepsis. Cytokine 9, 138-142.

Groszmann RJ (1993) Hyperdynamic state in chronic liver diseases. Journal of Hepatology 17, Suppl. 2, S38-S40.

Guarner C, Soriano G, Tomas A, Bulbena O, Novella MT, Balanzo J, Vilardell F, Mourelle M \& Moncada S (1993) Increased serum nitrite and nitrate levels in patients with cirrhosis: relationship to endotoxemia. Hepatology 18, 1139-1143.

Hallemeesch MM, Cobben DC, Soeters PB \& Deutz NE (2002a) Differential effects of selective and non-selective NOS inhibition on renal arginine and protein metabolism during endotoxemia in rats. Clinical Nutrition 21, 111-117.

Hallemeesch MM, Janssen BJ, De Jonge WJ, Soeters PB, Lamers WH \& Deutz NE (2003) Increased iNOS-mediated and decreased cNOS-mediated NO production reflect blood pressure changes in LPS-challenged mice. American Journal of Physiology 285, E871-E875.

Hallemeesch MM, Lamers WH \& Deutz NE (2002b) Reduced arginine availability and nitric oxide production. Clinical Nutrition 21, 273-279.

Hallemeesch MM, Soeters PB \& Deutz NE (2002c) Renal arginine and protein synthesis are increased during early endotoxemia in mice. American Journal of Physiology 282, F316-F323.

Hammarqvist F, Wernerman J, Ali R, von der Decken A \& Vinnars E (1989) Addition of glutamine to total parenteral nutrition after elective abdominal surgery spares free glutamine in muscle, counteracts the fall in muscle protein synthesis, and improves $n$ balance. Annals of Surgery 209, 455-461.

Harrison DG \& Cai H (2003) Endothelial control of vasomotion and nitric oxide production. Cardiology Clinics 21, 289-302.

Hazell AS \& Norenberg MD (1998) Ammonia and manganese increase arginine uptake in cultured astrocytes. Neurochemical Research 23, 869-873.

Helmer KS, West SD, Shipley GL, Chang L, Cui Y, Mailman D \& Mercer DW (2002) Gastric nitric oxide synthase expression during endotoxemia: implications in mucosal defense in rats. Gastroenterology 123, 173-186.

Helmy A, Newby DE, Jalan R, Johnston NR, Hayes PC \& Webb DJ (2003) Nitric oxide mediates the reduced vasoconstrictor response to angiotensin ii in patients with preascitic cirrhosis. Journal of Hepatology 38, 44-50.

Heyland DK, Novak F, Drover JW, Jain M, Su X \& Suchner U (2001) Should immunonutrition become routine in critically ill patients? A systematic review of the evidence. Journal of the American Medical Association 286, 944-953.
Heyland DK \& Samis A (2003) Does immunonutrition in patients with sepsis do more harm than good? Intensive Care Medicine 29, 669-671.

Heys SD \& Ashkanani F (1999) Glutamine. British Journal of Surgery 86, 289-290.

Heys SD \& Gardner E (1999) Nutrients and the surgical patient: current and potential therapeutic applications to clinical practice. Journal of the Royal College of Surgeons of Edinburgh 44 , 283-293.

Heys SD, Segar A, Payne S, Bruce DM, Kernohan N \& Eremin O (1997) Dietary supplementation with L-arginine: modulation of tumour-infiltrating lymphocytes in patients with colorectal cancer. British Journal of Surgery 84, 238-241.

Hibbs JB Jr, Vavrin Z \& Taintor RR (1987) L-Arginine is required for expression of the activated macrophage effector mechanism causing selective metabolic inhibition in target cells. Journal of Immunology 138, 550-565.

Hiltebrand LB, Krejci V, Banic A, Erni D, Wheatley AM \& Sigurdsson GH (2000) Dynamic study of the distribution of microcirculatory blood flow in multiple splanchnic organs in septic shock. Critical Care Medicine 28, 3233-3241.

Hoffman RA, Zhang G, Nussler NC, Gleixner SL, Ford HR, Simmons RL \& Watkins SC (1997) Constitutive expression of inducible nitric oxide synthase in the mouse ileal mucosa. American Journal of Physiology 272, G383-G392.

Hoogenraad N, Totino N, Elmer H, Wraight C, Alewood P \& Johns B (1985) Inhibition of intestinal citrulline synthesis causes severe growth retardation in rats. American Journal of Physiology 249, G792-G799.

Houdijk APJ, Rijnsburger ER, Jansen J, Wesdorp RIC, Weiss JK, McCamish MA, Teerlink T, Meuwissen SGM, Haarman HJTM, Thijs LG \& van Leeuwen PAM (1998a) Randomised trial of glutamine-enriched enteral nutrition on infectious morbidity in patients with multiple trauma. Lancet 352, 772-776.

Houdijk APJ, van Leeuwen PAM, Teerlink T, Flinkerbusch EL, Boermeester MA, Sauerwein HP \& Wesdorp RIC (1994) Glutamine-enriched enteral diet increases renal arginine production. Journal of Parenteral and Enteral Nutrition 18, 422-426.

Houdijk APJ, Visser JJ, Rijnsburger ER, Teerlink T \& van Leeuwen PAM (1998b) Dietary glutamine supplementation reduces plasma nitrate levels in rats. Clinical Nutrition 17, 11-14.

Ikemoto M, Tsunekawa S, Tanaka K, Tanaka A, Yamaoka Y, Ozawa K, Fukuda Y, Moriyasu F, Totani M, Kasai Y, Mori T \& Ueda K (1998) Liver-type arginase in serum during and after liver transplantation: a novel index in monitoring conditions of the liver graft and its clinical significance. Clinica Chimica Acta 271, 11-23.

Ito A, Tsao PS, Adimoolam S, Kimoto M, Ogawa T \& Cooke JP (1999) Novel mechanism for endothelial dysfunction: dysregulation of dimethylarginine dimethylaminohydrolase. Circulation 99, 3092-3095.

Jacobs DO, Evans DA, Mealy K, O’Dwyer ST, Smith RJ \& Wilmore DW (1988) Combined effects of glutamine and epidermal growth factor on the rat intestine. Surgery $\mathbf{1 0 4}$ $358-364$

Jalkanen M, Larjava H, Heino J, Vihersaari T, Peltonen J \& Penttinen R (1982) Arginine depletion in macrophage medium inhibits collagen synthesis by fibroblasts. Immunology Letters 4, 259-261.

Jayasurya A, Dheen ST, Yap WM, Tan NG, Ng YK \& Bay BH (2003) Inducible nitric oxide synthase and bcl-2 expression in nasopharyngeal cancer: correlation with outcome of patients after radiotherapy. International Journal of Radiation Oncology, Biology, Physics 56, 837-845.

John S \& Schmieder RE (2003) Potential mechanisms of impaired 
endothelial function in arterial hypertension and hypercholesterolemia. Current Hypertension Reports 5, 199-207.

Ju H, Zou R, Venema VJ \& Venema RC (1997) Direct interaction of endothelial nitric-oxide synthase and caveolin-1 inhibits synthase activity. Journal of Biological Chemistry 272, 18522-18525.

Kampfer H, Pfeilschifter J \& Frank S (2003) Expression and activity of arginase isoenzymes during normal and diabetesimpaired skin repair. Journal of Investigative Dermatology 121, 1544-1551.

Katchman AN \& Hershkowitz N (1997) Nitric oxide modulates synaptic glutamate release during anoxia. Neuroscience Letters 228, 50-54.

Kato S, Esumi H, Hirano A, Kato M, Asayama K \& Ohama E (2003) Immunohistochemical expression of inducible nitric oxide synthase (iNOS) in human brain tumors: relationships of iNOS to superoxide dismutase (SOD) proteins (SOD1 and SOD2), Ki-67 antigen (Mib-1) and P53 protein. Acta Neuropathologica 105, 333-340.

Kelly E, Morris SM Jr \& Billiar TR (1995) Nitric oxide, sepsis, and arginine metabolism. Journal of Parenteral and Enteral Nutrition 19, 234-238.

Keskinege A, Elgun S \& Yilmaz E (2001) Possible implications of arginase and diamine oxidase in prostatic carcinoma. Cancer Detection and Prevention 25, 76-79.

Kielstein JT, Bode-Boger SM, Frolich JC, Ritz E, Haller H \& Fliser D (2003) Asymmetric dimethylarginine, blood pressure, and renal perfusion in elderly subjects. Circulation 107, $1891-1895$.

Kilbourn R (1999) Nitric oxide synthase inhibitors - a mechanism-based treatment of septic shock. Critical Care Medicine 27, 857-858.

Kirk SJ \& Barbul A (1990) Role of arginine in trauma, sepsis, and immunity. Journal of Parenteral and Enteral Nutrition 14, 226S-229S

Kirk SJ, Hurson M, Regan MC, Holt DR, Wasserkrug HL \& Barbul A (1993) Arginine stimulates wound healing and immune function in elderly human beings. Surgery 114, 155-159; discussion 160.

Kirkeboen KA \& Strand OA (1999) The role of nitric oxide in sepsis - an overview. Acta Anaesthesiologica 43, 275-288.

Klimberg VS, Salloum RM, Kasper M, Plumley DA, Dolson DJ, Hautamaki RD, Mendenhall WR, Bova FC, Bland KI, Copeland EM \& Souba WW (1990a) Oral glutamine accelerates healing of the small intestine and improves outcome after whole abdominal radiation. Archives of Surgery 125, $1040-1045$.

Klimberg VS, Souba WW, Salloum RM, Holley DT, Hautamaki RD, Dolson DJ \& Copeland EM (1990b) Intestinal glutamine metabolism after massive small bowel resection. American Journal of Surgery 159, 27-33.

Kong G, Kim EK, Kim WS, Lee KT, Lee YW, Lee JK, Paik SW \& Rhee JC (2002) Role of cyclooxygenase-2 and inducible nitric oxide synthase in pancreatic cancer. Journal of Gastroenterology and Hepatology 17, 914-921.

Konig P, Dedio J, Muller-Esterl W \& Kummer W (2002) Distribution of the novel eNOS-interacting protein NOSIP in the liver, pancreas, and gastrointestinal tract of the rat. Gastroenterology 123, 314-324.

Kubota A, Meguid MM \& Hitch DC (1992) Amino acid profiles correlate diagnostically with organ site in three kinds of malignant tumors. Cancer 69, 2343-2348.

Lancaster JR Jr \& Hibbs JB Jr (1990) EPR demonstration of Fenitrosyl complex formation by cytotoxic activated macrophages. Proceedings of the National Acadamy of Sciences USA 87, 1223-1227.

Langle F, Roth E, Steininger R, Winkler S \& Muhlbacher F (1995) Arginase release following liver reperfusion. Evidence of hemodynamic action of arginase infusions. Transplantation 59, 1542-1549.

Langle F, Steininger R, Waldmann E, Grunberger T, Benditte H, Mittlbock M, Soliman T, Schindl M, Windberger U, Muhlbacher F \& Roth E (1997) Improvement of cardiac output and liver blood flow and reduction of pulmonary vascular resistance by intravenous infusion of L-arginine during the early reperfusion period in pig liver transplantation. Transplantation 63, $1225-1233$.

Lavoie J, Giguere JF, Layrargues GP \& Butterworth RF (1987) Amino acid changes in autopsied brain tissue from cirrhotic patients with hepatic encephalopathy. Journal of Neurochemistry 49, 692-697.

Lee PC, Salyapongse AN, Bragdon GA, Shears LL II, Watkins SC, Edington HD \& Billiar TR (1999) Impaired wound healing and angiogenesis in eNOS-deficient mice. American Journal of Physiology 277, H1600-H1608.

Lee RH, Efron D, Tantry U \& Barbul A (2001) Nitric oxide in the healing wound: a time-course study. Journal of Surgical Research 101, 104-108.

Lee TW, Chen GG, Xu H, Yip JH, Chak EC, Mok TS \& Yim AP (2003) Differential expression of inducible nitric oxide synthase and peroxisome proliferator-activated receptor gamma in nonsmall cell lung carcinoma. European Journal of Cancer 39, 1296-1301.

Lentsch AB, Yoshidome H, Cheadle WG, Miller FN \& Edwards MJ (1998) Chemokine involvement in hepatic ischemia/reperfusion injury in mice: roles for macrophage inflammatory protein-2 and Kc. Hepatology 27, 1172-1177.

Lieberman MD, Nishioka K, Redmond HP \& Daly JM (1992) Enhancement of interleukin-2 immunotherapy with L-arginine. Annals of Surgery 215, 157-165.

Lin KY, Ito A, Asagami T, Tsao PS, Adimoolam S, Kimoto M, Tsuji H, Reaven GM \& Cooke JP (2002) Impaired nitric oxide synthase pathway in diabetes mellitus: role of asymmetric dimethylarginine and dimethylarginine dimethylaminohydrolase. Circulation 106, 987-992.

Liu Q, Chan ST \& Mahendran R (2003) Nitric oxide induces cyclooxygenase expression and inhibits cell growth in colon cancer cell lines. Carcinogenesis 24, 637-642.

Lorente JA, Delgado MA, Tejedor C, Mon E, Hervas M, Pascual T, Fernandez-Segoviano P, Rieppi G, Soler A, Ayuso D \& Esteban A (1999) Modulation of systemic hemodynamics by exogenous L-arginine in normal and bacteremic sheep. Critical Care Medicine 27, 2474-2479.

Lorente JA, Landin L, De Pablo R, Renes E \& Liste D (1993a) LArginine pathway in the sepsis syndrome. Critical Care Medicine 21, 1287-1295.

Lorente JA, Landin L, Renes E, De Pablo R, Jorge P, Rodena E \& Liste D (1993b) Role of nitric oxide in the hemodynamic changes of sepsis. Critical Care Medicine 21, 759-767.

Lubec B, Hoeger H, Kremser K, Amann G, Koller DY \& Gialamas J (1996) Decreased tumor incidence and increased survival by one year oral low dose arginine supplementation in the mouse. Life Sciences 58, 2317-2325.

Luiking YC \& Deutz NE (2003) Isotopic investigation of nitric oxide metabolism in disease. Current Opinion in Clinical Nutrition and Metabolic Care 6, 103-108.

MacAllister RJ, Parry H, Kimoto M, Ogawa T, Russell RJ, Hodson H, Whitley GS \& Vallance P (1996) Regulation of nitric oxide synthesis by dimethylarginine dimethylaminohydrolase. British Journal of Pharmacology 119, 1533-1540.

McCarter MD, Gentilini OD, Gomez ME \& Daly JM (1998) Preoperative oral supplement with immunonutrients in cancer patients. Journal of Parenteral and Enteral Nutrition 22, 206-211. 
MacKenzie IM, Garrard CS \& Young JD (2001) Indices of nitric oxide synthesis and outcome in critically ill patients. Anaesthesia 56, 326-330.

Manders S, Poeze M, Ramsay G, Greve JWM \& Deutz NEP (1999) Plasma nitrate in surviving patients with septic shock are increased compared with non-survivors. Intensive Care Medicine 25, S86

Mendes RV, Martins AR, de Nucci G, Murad F \& Soares FA (2001) Expression of nitric oxide synthase isoforms and nitrotyrosine immunoreactivity by B-cell non-Hodgkin's lymphomas and multiple myeloma. Histopathology 39, 172-178.

Milewski PJ, Threlfall CJ, Heath DF, Holbrook IB, Wilford K \& Irving MH (1982) Intracellular free amino acids in undernourished patients with or without sepsis. Clinical Science (London) 62, 83-91.

Miller MJ, Thompson JH, Zhang XJ, et al. (1995) Role of inducible nitric oxide synthase expression and peroxynitrite formation in guinea pig ileitis. Gastroenterology 109, 1475-1483.

Millis RM, Diya CA, Reynolds ME, Dehkordi O \& Bond V Jr (1998) Growth inhibition of subcutaneously transplanted hepatomas without cachexia by alteration of the dietary arginine-methionine balance. Nutrition and Cancer 31, 49-55.

Milner JA \& Stepanovich LV (1979) Inhibitory effect of dietary arginine on growth of Ehrlich ascites tumor cells in mice. Journal of Nutrition 109, 489-494.

Mishima S, Xu D, Lu Q \& Deitch EA (1998) The relationships among nitric oxide production, bacterial translocation, and intestinal injury after endotoxin challenge in vivo. Journal of Trauma 44, 175-182.

Moffat FL Jr, Han T, Li ZM, Peck MD, Jy W, Ahn YS, Chu AJ \& Bourguignon LY (1996) Supplemental L-arginine $\mathrm{HCl}$ augments bacterial phagocytosis in human polymorphonuclear leukocytes. Journal of Cellular Physiology 168, 26-33.

Morel F, Hus-Citharel A \& Levillain O (1996) Biochemical heterogeneity of arginine metabolism along the kidney proximal tubules. Kidney International 49, 1608-1610.

Morris SM Jr \& Billiar TR (1994) New insights into the regulation of inducible nitric oxide synthesis. American Journal of Physiology 266, E829-E839.

Mungrue IN, Bredt DS, Stewart DJ \& Husain M (2003) From molecules to mammals: what's NOS got to do with it? Acta Physiologica Scandinavica 179, 123-135.

Murohara T, Asahara T, Silver M, Bauters C, Masuda H, Kalka C, Kearney M, Chen D, Symes JF, Fishman MC, Huang PL \& Isner JM (1998) Nitric oxide synthase modulates angiogenesis in response to tissue ischemia. Journal of Clinical Investigations 101, 2567-2578.

Murrell GA, Szabo C, Hannafin JA, Jang D, Dolan MM, Deng XH, Murrell DF \& Warren RF (1997) Modulation of tendon healing by nitric oxide. Inflammation Research 46, 19-27.

Naini AB, Dickerson JW \& Brown MM (1988) Preoperative and postoperative levels of plasma protein and amino acid in esophageal and lung cancer patients. Cancer 62, 355-360.

Nakae H, Endo S, Kikuchi M, Yamada Y, Shibata M, Ishikura H, Tanaka T, Wakabayashi G, Kawamura T, Inada K \& Sato S (2000) Nitrite/nitrate (NOx) levels and hemodynamics during septic shock. Surgery Today 30, 683-688.

Napoli C (2002) Nitric oxide and atherosclerotic lesion progression: an overview. Journal of Cardiac Surgery 17, 355-362.

Napoli C \& Ignarro LJ (2001) Nitric oxide and atherosclerosis. Nitric Oxide 5, 88-97.

Newsholme EA \& Leech AR (1983) Biochemistry for the Medical Sciences. New York: John Wiley \& Sons.

Nijveldt RJ, Teerlink T, Siroen MP, van Lambalgen AA, Rauwerda JA \& van Leeuwen PA (2003a) The liver is an important organ in the metabolism of asymmetrical dimethylarginine (ADMA). Clinical Nutrition 22, 17-22.
Nijveldt RJ, Teerlink T, van Der Hoven B, Siroen MP, Kuik DJ, Rauwerda JA \& van Leeuwen PA (2003b) Asymmetrical dimethylarginine (ADMA) in critically ill patients: high plasma adma concentration is an independent risk factor of ICU mortality. Clinical Nurtition 22, 23-30.

Nirgiotis JG, Hennessey PJ \& Andrassy RJ (1991) The effects of an arginine-free enteral diet on wound healing and immune function in the postsurgical rat. Journal of Pediatric Surgery 26, 936-941.

Nixon DW, Heymsfield SB, Cohen AE, Kutner MH, Ansley J, Lawson DH \& Rudman D (1980) Protein-calorie undernutrition in hospitalized cancer patients. American Journal of Medicine 68, 683-690.

Norris KA, Schrimpf JE, Flynn JL \& Morris SM Jr (1995) Enhancement of macrophage microbicidal activity: supplemental arginine and citrulline augment nitric oxide production in murine peritoneal macrophages and promote intracellular killing of Trypanosoma cruzi. Infection and Immunity $\mathbf{6 3}$ 2793-2796.

Novaes MR, Lima LA, Ribeiro JE, Magalhaes AV, Sousa MV \& Morhy L (2000) Pharmacological effects of arginine supplementation in rats with Walker 256 solid tumor (in Portuguese). Archivos Latinoamericanos de Nutricon 50, 230-236.

Ochoa JB, Udekwu AO, Billiar TR, Curran RD, Cerra FB, Simmons RL \& Peitzman AB (1991) Nitrogen oxide levels in patients after trauma and during sepsis. Annals of Surgery 214, 621-626.

O’Dwyer ST, Smith RJ, Hwang TL \& Wilmore DW (1989) Maintenance of small bowel mucosa with glutamine-enriched parenteral nutrition. Journal of Parenteral and Enteral Nutrition 13, 579-585.

Ogawa T, Kimoto M \& Sasaoka K (1987) Occurrence of a new enzyme catalyzing the direct conversion of NG,NG-dimethyl-Larginine to L-citrulline in rats. Biochemical and Biophysical Research Communications 148, 671-677.

Oka T, Ohwada K, Nagao M \& Kitazato K (1993) Effect of arginine-enriched total parenteral nutrition on the host-tumor interaction in cancer-bearing rats. Journal of Parenteral and Enteral Nutrition 17, 375-383.

Oka T, Ohwada K, Nagao M, Kitazato K \& Kishino Y (1994) Arginine-enriched solution induces a marked increase in muscle glutamine concentration and enhances muscle protein synthesis in tumor-bearing rats. Journal of Parenteral and Enteral Nutrition 18, 491-496.

Oudenhoven IM, Klaasen HL, Lapre JA, Weerkamp AH \& Van der Meer R (1994a) Nitric oxide-derived urinary nitrate as a marker of intestinal bacterial translocation in rats. Gastroenterology 107, 47-53.

Oudenhoven IMJ, Klaasen HLBM, Lapre JA, Weerkamp AH \& Van der Meer R (1994b) Nitric oxide-derived urinary nitrate as a marker of intestinal bacterial translocation in rats. Gastroenterology 107, 47-53.

Park KG, Heys SD, Blessing K, Kelly P, McNurlan MA, Eremin O \& Garlick PJ (1992) Stimulation of human breast cancers by dietary L-arginine. Clinical Science (London) 82, 413-417.

Park KG, Heys SD, Harris CI, Steele RJ, McNurlan MA, Eremin O \& Garlick PJ (1991) Arginine metabolism in benign and malignant disease of breast and colon: evidence for possible inhibition of tumor-infiltrating macrophages. Nutrition $\mathbf{7}$, $185-188$.

Parrillo JE (1993) Pathogenetic mechanisms of septic shock. New England Journal of Medicine 328, 1471-1477.

Patel A, Fenton C, Terrell R, Powers PA, Dinauer C, Tuttle RM \& Francis GL (2002) Nitrotyrosine, inducible nitric oxide synthase (iNOS), and endothelial nitric oxide synthase (eNOS) are increased in thyroid tumors from children and adolescents. Journal of Endocrinological Investigation 25, 675-683. 
Perez GO, Epstein M, Rietberg B \& Loutzenhiser R (1978) Metabolism of arginine by the isolated perfused rat kidney. American Journal of Physiology 235, F376-F380.

Poeze M, Greve JW \& Ramsay G (1999) Oxygen delivery in septic shock. Chest 116, 1145.

Porembska Z, Luboinski G, Chrzanowska A, Mielczarek M, Magnuska J \& Baranczyk-Kuzma A (2003) Arginase in patients with breast cancer. Clinica Chimica Acta 328, 105-111.

Preiser JC, De Backer D \& Vincent JL (2003) Nitroglycerin for septic shock. Lancet 361, 880 .

Preli RB, Klein KP \& Herrington DM (2002) Vascular effects of dietary L-arginine supplementation. Atherosclerosis 162, 1-15.

Prior BM, Lloyd PG, Ren J, Li Z, Yang HT, Laughlin MH \& Terjung RL (2003) Arteriogenesis: role of nitric oxide. Endothelium 10, 207-216.

Rao VL, Audet RM \& Butterworth RF (1995) Increased nitric oxide synthase activities and $\mathrm{L}-\left[{ }^{3} \mathrm{H}\right]$ arginine uptake in brain following portacaval anastomosis. Journal of Neurochemistry $\mathbf{6 5}$, 677-678.

Rao VL, Audet RM \& Butterworth RF (1997) Increased neuronal nitric oxide synthase expression in brain following portacaval anastomosis. Brain Research 765, 169-172.

Reade MC, Clark MF, Young JD \& Boyd CA (2002) Increased cationic amino acid flux through a newly expressed transporter in cells overproducing nitric oxide from patients with septic shock. Clinical Science (London) 102, 645-650.

Rekka EA \& Chrysselis MC (2002) Nitric oxide in atherosclerosis. Mini Reviews in Medicinal Chemistry 2, 585-593.

Rettura G, Padawer J, Barbul A, Levenson SM \& Seifter E (1979) Supplemental arginine increases thymic cellularity in normal and murine sarcoma virus-inoculated mice and increases the resistance to murine sarcoma virus tumor. Journal of Parenteral and Enteral Nutrition 3, 409-416.

Reynolds JV, Daly JM, Shou J, Sigal R, Ziegler MM \& Naji A (1990) Immunologic effects of arginine supplementation in tumor-bearing and non-tumor-bearing hosts. Annals of Surgery 211, 202-210

Reynolds JV, Daly JM, Zhang S, Evantash E, Shou J, Sigal R \& Ziegler MM (1988a) Immunomodulatory mechanisms of arginine. Surgery 104, 142-151.

Reynolds JV, Thom AK, Zhang SM, Ziegler MM, Naji A \& Daly JM (1988b) Arginine, protein malnutrition, and cancer. Journal of Surgical Research 45, 513-522.

Riso S, Aluffi P, Brugnani M, Farinetti F, Pia F \& D'Andrea F (2000) Postoperative enteral immunonutrition in head and neck cancer patients. Clinical Nutrition 19, 407-412.

Rockey DC (2003) Vascular mediators in the injured liver. Hepatology 37, 4-12.

Rose WC (1976) Nutrition Classics. Federation Proceedings 8(2)546-52, June 1949. Amino acid requirements of man. William C. Rose. Nutrition Reviews 34, 307-309.

Rose WC, Oesterling MJ \& Womack M (1948) Comparative growth on diets containing ten and nineteen amino acids, with further observations on the role of glutamic and aspartic acids. Journal of Biological Chemistry 176, 753-762.

Roth E (1998) L-Arginine-nitric oxide metabolism. Glutamine: a new player in this metabolic game? Clinical Nutrition 17, 1-2.

Santak B, Radermacher P, Iber T, Adler J, Wachter U, Vassilev D, Georgieff M \& Vogt J (1997) In vivo quantification of endotoxin-induced nitric oxide production in pigs from $\mathrm{Na}^{15} \mathrm{NO}_{3}$ infusion. British Journal of Pharmacology 122, 1605-1610.

Sarela AI, Mihaimeed FM, Batten JJ, Davidson BR \& Mathie RT (1999) Hepatic and splanchnic nitric oxide activity in patients with cirrhosis. Gut 44, 749-753.

Schaffer MR, Tantry U, Thornton FJ \& Barbul A (1999) Inhibition of nitric oxide synthesis in wounds: pharmacology and effect on accumulation of collagen in wounds in mice. European Journal of Surgery 165, 262-267.
Schaffer MR, Tantry U, van Wesep RA \& Barbul A (1997) Nitric oxide metabolism in wounds. Journal of Surgical Research 71, $25-31$.

Scheppach W, Loges C, Bartram P, Christl SU, Richter F, Dusel G, Stehle P, Furst P \& Kaspar H (1994) Effect of free glutamine and alanyl-glutamine dipeptide on mucosal proliferation of the human ileum and colon. Gastroenterology 107, 429-434.

Schutte H, Mayer K, Gessler T, Ruhl M, Schlaudraff J, Burger H, Seeger W \& Grimminger F (1998) Nitric oxide biosynthesis in an exotoxin-induced septic lung model: role of cNOS and impact on pulmonary hemodynamics. American Journal of Respiratory and Critical Care Medicine 157, 498-504.

Schwartz D, Schwartz IF, Gnessin E, Wollman Y, Chernichovsky T, Blum M \& Iaina A (2003) Differential regulation of glomerular arginine transporters (CAT-1 and CAT-2) in lipopolysaccharidetreated rats. American Journal of Physiology 284, F788-F795.

Scott JA, Mehta S, Duggan M, Bihari A \& McCormack DG (2002) Functional inhibition of constitutive nitric oxide synthase in a rat model of sepsis. American Journal of Respiratory and Critical Care Medicine 165, 1426-1432.

Seifter E, Rettura G, Barbul A \& Levenson SM (1978) Arginine: an essential amino acid for injured rats. Surgery 84, 224-230.

Shah V, Toruner M, Haddad F, Cadelina G, Papapetropoulos A, Choo K, Sessa WC \& Groszmann RJ (1999) Impaired endothelial nitric oxide synthase activity associated with enhanced caveolin binding in experimental cirrhosis in the rat. Gastroenterology 117, 1222-1228.

Shashidharan M, Lin KM, Ternent CA, Smyrk TC, Thorson AG, Blatchford GJ \& Christensen MA (1999) Influence of arginine dietary supplementation on healing colonic anastomosis in the rat. Diseases of the Colon and Rectum 42, 1613-1617.

Shi HP, Efron DT, Most D, Tantry US \& Barbul A (2000) Supplemental dietary arginine enhances wound healing in normal but not inducible nitric oxide synthase knockout mice. Surgery 128, 374-378.

Shi HP, Most D, Efron DT, Tantry U, Fischel MH \& Barbul A (2001) The role of iNOS in wound healing. Surgery 130, 225-229.

Sigal RK, Shou J \& Daly JM (1992) Parenteral arginine infusion in humans: nutrient substrate or pharmacologic agent? Journal of Parenteral and Enteral Nutrition 16, 423-428.

Strand OA, Leone A, Giercksky KE \& Kirkeboen KA (2000) Nitric oxide indices in human septic shock. Critical Care Medicine 28, 2779-2785.

Stuehr DJ \& Nathan CF (1989) Nitric oxide. A macrophage product responsible for cytostasis and respiratory inhibition in tumor target cells. Journal of Experimental Medicine 169, 1543-1555.

Suer Gokmen S, Yoruk Y, Cakir E, Yorulmaz F \& Gulen S (1999) Arginase and ornithine, as markers in human non-small cell lung carcinoma. Cancer Biochemistry Biophysics 17, 125-131.

Sukumar P, Loo A, Magur E, Nandi J, Oler A \& Levine RA (1997) Dietary supplementation of nucleotides and arginine promotes healing of small bowel ulcers in experimental ulcerative ileitis. Digestive Diseases and Sciences 42, 1530-1536.

Symeonides S \& Balk RA (1999) Nitric oxide in the pathogenesis of sepsis. Infectious Disease Clinics of North America 13, 449-463.

Szabo C (1996) The pathophysiological role of peroxynitrite in shock, inflammation, and ischemia-reperfusion injury. Shock $\mathbf{6}$, 79-88.

Szende B, Tyihak E \& Trezl L (2001) Role of arginine and its methylated derivatives in cancer biology and treatment. Cancer Cell International 1, 3.

Tachibana K, Mukai K, Hiraoka I, Moriguchi S, Takama S \& Kishino Y (1985) Evaluation of the effect of arginine-enriched amino acid solution on tumor growth. Journal of Parenteral and Enteral Nutrition 9, 428-434. 
Tajiri K, Miyakawa H, Izumi N, Marumo F \& Sato C (1995) Systemic hypotension and diuresis by L-arginine in cirrhotic patients with ascites: role of nitric oxide. Hepatology 22, 1430-1435.

Takeda Y, Tominaga T, Tei N, Kitamura M \& Taga S (1975) Inhibitory effect of L-arginine on growth of rat mammary tumors induced by 7,12-dimethylbenz(a)anthracene. Cancer Research 35, 2390-2393.

Tamir S, Burney S \& Tannenbaum SR (1996) DNA damage by nitric oxide. Chemical Research in Toxicology 9, 821-827.

Tentolouris C, Tousoulis D, Goumas G, Stefanadis C, Davies G \& Toutouzas P (2000) L-Arginine in coronary atherosclerosis. International Journal of Cardiology 75, 123-128.

Thomsen LL, Miles DW, Happerfield L, Bobrow LG, Knowles RG \& Moncada S (1995) Nitric oxide synthase activity in human breast cancer. British Journal of Cancer 72, 41-44.

Tietge UJ, Bahr MJ, Manns MP \& Boker KH (2002) Plasma amino acids in cirrhosis and after liver transplantation: influence of liver function, hepatic hemodynamics and circulating hormones. Clinical Transplantation 16,9-17.

Titheradge MA (1999) Nitric oxide in septic shock. Biochimica et Biophysica Acta 1411, 437-455.

Tizianello A, de Ferrari G, Garibotto G, Guerreri G \& Robaudo C (1980) Renal metabolism of amino acids and ammonia in subjects with normal renal function and in patients with chronic renal insufficiency. Journal of Clinical Investigations 65, 1162-1173.

Tizianello A, Deferrari G, Garibotto G, Robaudo C, Salvidio G \& Saffiotti S (1985) Renal ammoniagenesis in the postprandial period. Contributions to Nephrology 47, 44-57.

Tousoulis D, Antoniades C, Tentolouris C, Goumas G, Stefanadis C \& Toutouzas P (2002) L-Arginine in cardiovascular disease: dream or reality? Vascular Medicine 7, 203-211.

Tschugguel W, Schneeberger C, Unfried G, Czerwenka K, Weninger W, Mildner M, Gruber DM, Sator MO, Waldhor T \& Huber JC (1999) Expression of inducible nitric oxide synthase in human breast cancer depends on tumor grade. Breast Cancer Research and Treatment 56, 145-151.

Tzeng E \& Billiar TR (1997) Nitric oxide and the surgical patient. Archives of Surgery 132, 977-982.

Ulibarri JA, Mozdziak PE, Schultz E, Cook C \& Best TM (1999) Nitric oxide donors, sodium nitroprusside and S-nitroso-Nacetylpencillamine, stimulate myoblast proliferation in vitro. In Vitro Cellular and Development Biology. Animal 35, 215-218.

Unno N, Wang H, Menconi MJ, Tytgat SH, Larkin V, Smith M, Morin MJ, Chavez A, Hodin RA \& Fink MP (1997) Inhibition of inducible nitric oxide synthase ameliorates endotoxininduced gut mucosal barrier dysfunction in rats. Gastroenterology 113, 1246-1257.

Vakkala M, Kahlos K, Lakari E, Paakko P, Kinnula V \& Soini Y (2000) Inducible nitric oxide synthase expression, apoptosis, and angiogenesis in in situ and invasive breast carcinomas. Clinical Cancer Research 6, 2408-2416.

Vallance P, Leone A, Calver A, Collier J \& Moncada S (1992) Endogenous dimethylarginine as an inhibitor of nitric oxide synthesis. Journal of Cardiovascular Pharmacology 20, Suppl. 12, S60-S62.

Vallance P \& Moncada S (1991) Hyperdynamic circulation in cirrhosis: a role for nitric oxide? Lancet 337, 776-778.

van Bokhorst-de van der Schueren MA, Quak JJ, von Blombergvan der Flier BM, Kuik DJ, Langendoen SI, Snow GB, Green CJ \& van Leeuwen PA (2001) Effect of perioperative nutrition, with and without arginine supplementation, on nutritional status, immune function, postoperative morbidity, and survival in severely malnourished head and neck cancer patients. American Journal of Clinical Nutrition 73, 323-332. van der Hulst RR, von Meyenfeldt MF, Deutz NE \& Soeters PB (1997) Glutamine extraction by the gut is reduced in depleted [corrected] patients with gastrointestinal cancer. Annals of Surgery 225, 112-121.

van der Hulst RRWJ, Deutz NEP, von Meyenfeldt MF, Elbers JMH, Stockbrugger RW \& Soeters PB (1994) Decrease of mucosal glutamine concentration in the nutritionally depleted patient. Clinical Nutrition 13, 228-233.

van der Hulst RRWJ, van Kreel BK, von Meyenfeldt MF, Brummer R-JM, Arends J-W, Deutz NEP \& Soeters PB (1993) Glutamine and the preservation of gut integrity. Lancet 341, 1363-1365.

Vincent JL, Zhang H, Szabo C \& Preiser JC (2000) Effects of nitric oxide in septic shock. American Journal of Respiratory and Critical Care Medicine 161, 1781-1785.

Visek WJ (1986) Arginine needs, physiological state and usual diets. A reevaluation. Journal of Nutrition 116, 36-46.

Wakabayashi Y, Yamada E, Yoshida T \& Takahashi N (1995) Effect of intestinal resection and arginine-free diet on rat physiology. American Journal of Physiology 269, G313-G318.

Wang J, Torbenson M, Wang Q, Ro JY \& Becich M (2003) Expression of inducible nitric oxide synthase in paired neoplastic and non-neoplastic primary prostate cell cultures and prostatectomy specimen. Urologic Oncology 21, 117-122.

Weller R (2003) Nitric oxide: a key mediator in cutaneous physiology. Clinical and Experimental Dermatology 28, 511-514.

Wenzel U, Kuntz S, De Sousa UJ \& Daniel H (2003) Nitric oxide suppresses apoptosis in human colon cancer cells by scavenging mitochondrial superoxide anions. International Journal of Cancer 106, 666-675.

Wernerman J (1998) Glutamine-containing TPN: a question of life and death for intensive care unit-patients? Clinical Nutrition $\mathbf{1 7}$ 3-6.

White MF (1985) The transport of cationic amino acids across the plasma membrane of mammalian cells. Biochimica et Biophysica Acta 822, 355-374.

Windmueller HG \& Spaeth AE (1975) Intestinal metabolism of glutamine and glutamate from the lumen as compared to glutamine from blood. Archives of Biochemistry and Biophysics 171, $662-672$.

Windmueller HG \& Spaeth AE (1976) Metabolism of absorbed aspartate, asparagine, and arginine by rat small intestine in vivo. Archives of Biochemistry and Biophysics 175, 670-676.

Windmueller HG \& Spaeth AE (1978) Identification of ketone bodies and glutamine as the major respiratory fuels in vivo for postabsorptive rat small intestine. Journal of Biological Chemistry 253, 69-76.

Windmueller HG \& Spaeth AE (1981) Source and fate of circulating citrulline. American Journal of Physiology 241, E473-E480.

Wink DA, Cook JA, Pacelli R, DeGraff W, Gamson J, Liebmann J, Krishna MC \& Mitchell JB (1996) The effect of various nitric oxide-donor agents on hydrogen peroxide-mediated toxicity: a direct correlation between nitric oxide formation and protection. Archives of Biochemistry and Biophysics 331, 241-248.

Wink DA, Vodovotz Y, Laval J, Laval F, Dewhirst MW \& Mitchell JB (1998) The multifaceted roles of nitric oxide in cancer. Carcinogenesis 19, 711-721.

Witte MB \& Barbul A (2002) Role of nitric oxide in wound repair. American Journal of Surgery 183, 406-412.

Witte MB, Barbul A, Schick MA, Vogt N \& Becker H D (2002a) Upregulation of arginase expression in wound-derived fibroblasts. Journal of Surgical Research 105, 35-42.

Witte MB, Kiyama T \& Barbul A (2002b) Nitric oxide enhances experimental wound healing in diabetes. British Journal of Surgery 89, 1594-1601.

Witte MB, Thornton FJ, Tantry U \& Barbul A (2002c) L-Arginine 
supplementation enhances diabetic wound healing: involvement of the nitric oxide synthase and arginase pathways. Metabolism 51, 1269-1273.

Wolf H, Haeckel C \& Roessner A (2000) Inducible nitric oxide synthase expression in human urinary bladder cancer. Virchows Archiv 437, 662-666.

Wu G \& Morris SM Jr (1998) Arginine metabolism: nitric oxide and beyond. Biochemical Journal 336, 1-17.

Xia Y, Dawson VL, Dawson TM, Snyder SH \& Zweier JL (1996) Nitric oxide synthase generates superoxide and nitric oxide in arginine-depleted cells leading to peroxynitrite-mediated cellular injury. Proceedings of the National Academy of Sciences USA 93, 6770-6774.

Yagnik GP, Takahashi Y, Tsoulfas G, Reid K, Murase N \& Geller DA (2002) Blockade of the L-arginine/NO synthase pathway worsens hepatic apoptosis and liver transplant preservation injury. Hepatology 36, 573-581.

Yeatman TJ, Risley GL \& Brunson ME (1991) Depletion of dietary arginine inhibits growth of metastatic tumor. Archives of Surgery 126, 1376-1381; discussion 1381-1382.
Yeh CL, Yeh SL, Lin MT \& Chen WJ (2002) Effects of arginineenriched total parenteral nutrition on inflammatory-related mediator and T-cell population in septic rats. Nutrition 18, $631-635$

Yoshie Y \& Ohshima H (1997) Nitric oxide synergistically enhances DNA strand breakage induced by polyhydroxyaromatic compounds, but inhibits that induced by the Fenton reaction. Archives of Biochemistry and Biophysics 342, 13-21.

Young VR \& Yu Y-M (1996) Protein and Amino Acid Metabolism, Chapter 6. Boston, MA: Little, Brown and Company.

Zhuang JC, Wright TL, deRojas-Walker T, Tannenbaum SR \& Wogan GN (2000) Nitric oxide-induced mutations in the HPRT gene of human lymphoblastoid TK6 cells and in Salmonella typhimurium. Environmental and Molecular Mutagenesis 35, 39-47.

Zimmermann K, Opitz N, Dedio J, Renne C, Muller-Esterl W \& Oess S (2002) NOSTRIN: a protein modulating nitric oxide release and subcellular distribution of endothelial nitric oxide synthase. Proceedings of the National Academy of Sciences USA 99, 17167-17172. 